\title{
Analysis of an Experimental Cortical Network: i) Architectonics of Visual Areas 17 and 18 After Neonatal Injections of Ibotenic Acid; Similarities with Human Microgyria
}

\author{
G.M. Innocenti and P. Berbel ${ }^{a}$ \\ Institute of Anatomy, University of Lausanne, Rue du Bugnon, \\ 1005 Lausanne, Switzerland
}

aPresent address:

Department of Histology and Institute of Neuroscience

Faculty of Medicine

University of Alicante

03690 Alicante, Spain.

\section{SUMMARY}

Lesions of cortical areas 17 and 18 have been produced in newborn kittens by local injections of the excitotoxin ibotenic acid (ibo). Twentyfour hours after an injection on postnatal days 2 or 3, the gray matter of areas 17 and 18 near the center of the injection appears completely destroyed, with the exception of a one-to-two cell-thick layer at the bottom of layer I. Intact migrating neurons and radial glia can be found light- and electron-microscopically in the region affected. During the following weeks a several hundred micron thick cortex reforms. In the adult, this cortex consists of superficial layers I, II and III as proven by cytoarchitectonics, continuity with the corresponding layers of the

Reprint address:

G.M. Innocenti

Institute of Anatomy,

University of Lausanne,

Rue du Bugnon 9

1005 Lausanne, Switzerland. normal cortex and cellular composition. We believe that the recovery is due to completion of migration by neurons spared by the ibo injection. More severe destruction of cerebral cortex, i.e. complete loss of the neuronal layers or their reduction to a few cell-thick mantles can be obtained with ibo injections at the end of the second or, respectively, first postnatal week. Severity of lesion also depends on the dose of ibo injected. There are interesting similarities between the ibo-injured cortex and two human neocortical displasias: microgyria and ulegyria.

Key words: cortex development, excitotoxins, microgyria, ibotenic acid.

\section{INTRODUCTION}

"Simple" neural circuits, whether created by evolution or tissue culture, have provided a wealth of information on cellular and molecular interactions in development. In a complex system, these mechanisms can provide reasonable $a$ posteriori explanatory hypotheses for a given morphogenetic event, but they are insufficient to predict the outcomes of normal, and even less abnormal development. Thus, the consequences of, for example, early vs. late brain lesions cannot be reliably predicted as indicated by recent debates on the so-called "Kennard principle" /44,52/. 
To a large extent, the fact that the development of a neural system cannot be easily reduced to that of its cellular and molecular components in isolation, is a direct consequence of its network properties. In a developing neural network, a localized structural change can have consequences far away from the site where it occurred. For example, experimental or genetic changes in the retinofugal projection can affect the development of visual callosal projections (for references see /19/). Furthermore, the operations a neural network performs, e.g., its input-output transformations, may have regulatory consequences on the local molecular events by which the network itself is assembled. For example, visual experience can modify the development of geniculo-cortical and callosal projections (for references see /19,63/) probably by affecting molecular mechanisms of synapse formation $/ 57 /$.

In this study and in two others $/ 1,21$, we explore the potentials of a "simplified" network, produced by neonatal, local injection of ibotenic acid (ibo) in the visual cortex of the cat for the analysis of the relations between structure and function in the developing and adult cortex. In particular, we focus on the regulation of the elimination of transient, juvenile projections to the visual cortex $/ 20,25 /$. Preliminary findings indicated that the neonatal injection of ibo results in the formation of a cortex consisting exclusively of supragranular layers; some of the normal response properties of visual cortical neurons are maintained although some of the transient projections to the visual cortex, which are normally eliminated in development, are maintained as well $/ 23 /$.

In a broad sense, the approach used resembles $x$-irradiation $/ 27,28,51 /$ or the administration of cytotoxic drugs interfering with cell proliferation $/ 30 /$, both of which, however, delete the superficial cortical layers. The usefulness of these approaches for the goals outlined above depends on the reproducibility of the results and on the possibility of fully characterizing the effects of the developmental manipulations. Because of its local action, the neonatal injection of ibo appears to be free of complications such as generalized loss of neuronal or glial populations throughout the brain, the production of neuronal ectopias which can, in contrast, result from $\mathrm{x}$-irradiation or cytotoxic drugs $/ 28 /$, etc. In addition, the cortex produced by neonatal ibo injections (henceforth referred to as microcortex) resembles "microgyria", a congenital malformation of the human cortex often associated with epilepsy, mental retardation and possibly dyslexia $/ 15,34,39,47 /$; it may therefore provide a model for the study of this malformation.

\section{MATERIALS AND METHODS}

Experiments were performed on 39 kittens, born in our breeding colony. About one half of the kittens were obtained from timed pregnancies and were delivered on day $65 \pm 2$ post-conception. All kittens received injections of ibo in areas 17 and 18 of the right hemisphere. Twenty-four to 48 hours before sacrifice, many of the kittens received injections of WGA-HRP alone or combined with $\left[{ }^{3} \mathrm{H}\right]$ leucine-proline in their visual or auditory areas. In one kitten, single unit recordings were performed in areas 17 and 18 on the side of ibo injection; another one was used for 2-deoxyglucose experiments. Modalities and results of these investigations will be described elsewhere /21/ (Assal et al., in preparation). Kittens were subdivided into four groups, aiming at different experimental questions.

The 15 kittens in the first group (Table 1) were injected with ibo $(1-2.5 \mu \mathrm{l} ; 30 \mu \mathrm{g} / \mu \mathrm{l}$ in $0.1 \mathrm{M}$ phosphate buffer $\mathrm{pH} 7.4$ ) on postnatal days (pd) 2-3 (day of birth $=\mathrm{pd} 0$ ) and killed either on pd 3-4 or 8-9.5 or 11-27; they were used to study the short-term consequences of the ibo injections. IBO 73 and 75 received one $\left[{ }^{3} \mathrm{H}\right]$ thymidine injection each $(2.5 \mathrm{mCi})$, respectively $12 \mathrm{~h}$ and 24 $\mathrm{h}$ after the ibo injection.

The 9 kittens in the second group (Table 2) were injected with ibo $(2-2.5 \mu \mathrm{l} ; 30 \mu \mathrm{g} / \mu \mathrm{l})$ on pd 1-3 and killed on pd 31-199; these kittens were used to study the long-term effects of the ibo injections.

The 9 kittens in the third group (Table 3) were injected with ibo on pd 2, 3 or 6 and killed between pd 5 and 328. Three concentrations of ibo were used: 10,20 and $30 \mu \mathrm{g} / \mu \mathrm{l}$ and the volume delivered varied between 0.5 and $2.8 \mu$ l. These kittens were used to study how the lesion depended on dose and concentration of ibo. Furthermore, in order to determine if in the 
TABLE 1. Short-survival experiments

\begin{tabular}{|c|c|c|c|c|c|c|c|}
\hline \multirow{3}{*}{$\begin{array}{l}\text { Animal } \\
\text { code }\end{array}$} & \multicolumn{2}{|c|}{ Age (days) } & \multirow{2}{*}{\multicolumn{2}{|c|}{$\begin{array}{l}\text { Dose } \\
\text { of IBO }\end{array}$}} & & \multicolumn{2}{|c|}{ Techniques used } \\
\hline & at IBO & at death & & & & Nissl & others \\
\hline & injection & & $(\mu l \mathrm{x}$ & & & & \\
\hline IBO 17 & 2 & 3 & 2.5 & $\mathbf{x}$ & 30 & $\mathbf{x}$ & $\mathrm{F}$, \\
\hline IBO 39 & 2 & 3 & 2 & $\mathbf{x}$ & 30 & $x$ & S, EM \\
\hline IBO 73 & 2.5 & 3.5 & 1 & $\mathbf{x}$ & 30 & $\mathrm{x}$ & P, $\left[{ }^{3} \mathrm{H}\right]$ Thy, GFAP, V \\
\hline IBO 90 & 2 & 4 & 1 & $\mathbf{x}$ & 30 & $\mathrm{x}$ & $\mathrm{P}, \mathrm{V}$ \\
\hline IBO 19 & 2 & 8 & 2.5 & $\mathbf{x}$ & 30 & $\mathbf{x}$ & $\mathrm{F}$ \\
\hline IBO 40 & 2 & 8 & 1.75 & $\mathbf{x}$ & 30 & $\mathrm{x}$ & S, EM \\
\hline IBO 75 & 2.5 & 9.5 & 1 & $\mathbf{x}$ & 30 & $\hat{x}$ & P, $\left[{ }^{3} \mathrm{H}\right]$ Thy, GFAP, V \\
\hline IBO 97 & 2 & 9 & 1 & $\mathbf{x}$ & 30 & $\mathbf{x}$ & $\mathrm{P}, \mathrm{V}$ \\
\hline IBO 47 & 3 & 11 & 1 & $\mathbf{x}$ & 30 & $\mathbf{x}$ & $\mathrm{F}$ \\
\hline IBO 92 & 2 & 13 & 1 & $\mathbf{x}$ & 30 & $\mathbf{x}$ & $\mathbf{P}$ \\
\hline IBO 98 & 2 & 14 & 1 & $\mathbf{x}$ & 30 & $\mathbf{x}$ & $\mathrm{F}$ \\
\hline IBO 104 & 3 & 14 & 1 & $\mathbf{x}$ & 30 & $x$ & $\mathbf{P}$ \\
\hline IBO 45 & 3 & 18 & 1 & $\mathbf{x}$ & 30 & $\mathrm{x}$ & $\mathbf{F}$ \\
\hline IBO 48 & 3 & 25 & 1 & $\mathbf{x}$ & 30 & $\mathrm{x}$ & $\mathrm{F}$ \\
\hline IBO 46 & 3 & 27 & 1 & $\mathbf{x}$ & 30 & $\mathrm{x}$ & F \\
\hline
\end{tabular}

F, frozen; S, spur; P, paraffin; EM, electron-microscopy; GFAP, glial fibrillary acidic protein immunohistochemistry; V, Vimentin immunohistochemistry; $\left[{ }^{3} \mathrm{H}\right] \mathrm{Thy},\left[{ }^{3} \mathrm{H}\right]$ Thymidine (for amounts and ages at injection, see Methods). All IBO injections were in right hemisphere. Several of these animals also received injections of WGA-HRP in areas 17 and 18 of the left hemisphere or in areas $\mathrm{A} 1$ and $\mathrm{A} 2$ of the right hemisphere.

TABLE 2. Long-survival experiments

\begin{tabular}{|c|c|c|c|c|c|c|c|}
\hline \multirow{3}{*}{$\begin{array}{l}\text { Animal } \\
\text { code }\end{array}$} & \multicolumn{2}{|c|}{ Age (days) } & \multirow{2}{*}{\multicolumn{2}{|c|}{$\begin{array}{l}\text { Dose } \\
\text { of IBO }\end{array}$}} & & \multicolumn{2}{|c|}{ Techniques used } \\
\hline & \multirow{2}{*}{$\begin{array}{l}\text { at IBO } \\
\text { injection }\end{array}$} & \multirow[t]{2}{*}{ at death } & & & & Nissl & others \\
\hline & & & $(\mu 1 \mathrm{x}$ & & & & \\
\hline IBO 7 & 2 & 81 & 2 & $\mathbf{x}$ & 30 & $\mathbf{x}$ & $F$ \\
\hline IBO 9 & 2 & 100 & 2 & $\mathbf{x}$ & 30 & $\mathrm{x}$ & $\mathrm{F}$ \\
\hline IBO 10 & 2 & 95 & 2 & $\mathbf{x}$ & 30 & $\mathrm{x}$ & F, CYT \\
\hline IBO 11 & 1 & 90 & 2.5 & $\mathbf{x}$ & 30 & $x$ & $\mathrm{~F}$ \\
\hline IBO 12 & 1 & 97 & 2.5 & $\mathbf{x}$ & 30 & $\mathbf{x}$ & $\mathrm{F}$ \\
\hline IBO 13 & 1 & 104 & 2.5 & $\mathbf{x}$ & 30 & $\mathbf{x}$ & $\mathrm{F}$ \\
\hline IBO 18 & 2 & 199 & 2.5 & $\mathbf{x}$ & 30 & $\mathbf{x}$ & F, CYT \\
\hline IBO 35 & 1 & 39 & 2 & $\mathbf{x}$ & 30 & $\mathbf{x}$ & S, Golgi \\
\hline IBO 63 & 3 & 52 & 2 & $\mathbf{x}$ & 30 & $\mathrm{x}$ & S, Golgi \\
\hline
\end{tabular}

CYT, cytochrome oxidase; other abbreviations as in Table 1. All ibo injections were in right hemisphere. Several of these animals also received injections of axonal tracers in areas 17 and 18 of the right or left hemisphere or in areas A1 and A2 of the right hemisphere. 
developing nervous system, as in the adult, the excitotoxic action of ibo is mediated by the $\mathrm{N}$ methyl-D-aspartate (NMDA) receptor, in two kittens (IBO 93 and 95) the NMDA antagonist phosphonovaleric acid (APV) /10/ was injected together with ibo and at equimolar concentrations in the right hemisphere. The left hemisphere received an identical injection of ibo, without APV.

The 6 kittens in the fourth group (Table 4) were injected with ibo $(1-2 \mu \mathrm{g} ; 30 \mu \mathrm{g} / \mu \mathrm{l})$ on pd 6 , 7,14 or 20 and killed between pd 52 and 167; they were used to study if a critical period existed for the effects of ibo.
Injections of ibo were performed in kittens premedicated with atropine and initially anesthetized with Ketalar (30-40 mg/kg i.m.) and subsequently by inhalation of a gas mixture containing $0.5-1.5 \%$ Penthrane in $70 \% \mathrm{~N}_{2} \mathrm{O}$ and $30 \% \quad \mathrm{O}_{2}$. Xylocaine (2\%) was applied to the wounds and to the periostium. Throughout the experiment, the body temperature of the kittens was controlled by a thermostatically regulated heating pad and the ECG was monitored. Glass pipettes (tip diameter 11-15 $\mu \mathrm{m}$ ) were filled with ibo by suction, lowered into the brain with a micromanipulator to the depth of $1200 \mu \mathrm{m}$ in pd 2 - 3 kittens, $1400 \mu \mathrm{m}$ in pd 6 or 7 kittens, 1500

TABLE 3. Effects of dose and NMDA receptor antagonist.

\begin{tabular}{|c|c|c|c|c|c|c|c|}
\hline \multirow{3}{*}{$\begin{array}{l}\text { Animal } \\
\text { code }\end{array}$} & \multicolumn{2}{|c|}{ Age (days) } & \multirow{2}{*}{\multicolumn{2}{|c|}{$\begin{array}{l}\text { Dose } \\
\text { of IBO }\end{array}$}} & & \multicolumn{2}{|c|}{ Techniques used } \\
\hline & at IBO & at death & & & & Nissl & others \\
\hline & \multicolumn{2}{|l|}{ injection } & \multicolumn{3}{|c|}{$\left(\mu 1 \times \frac{\mu g}{\mu l}\right)$} & & \\
\hline IBO 25 & 2 & 43 & 1 & $\mathbf{x}$ & 10 & $\mathbf{x}$ & $\mathrm{F}$ \\
\hline IBO 22 & 2 & 62 & 2 & $\mathbf{x}$ & 10 & $\mathbf{x}$ & $\mathrm{F}$ \\
\hline IBO 27 & 2 & 208 & $* 2$ & $\mathbf{x}$ & 10 & $\mathbf{x}$ & $\mathbf{F}$ \\
\hline IBO 26 & 2 & 55 & * 2.8 & $\mathbf{x}$ & 10 & $\mathbf{x}$ & $\mathbf{F}$ \\
\hline IBO 30 & 2 & 196 & 0.5 & $\mathbf{x}$ & 20 & $\mathbf{x}$ & $\mathbf{F}$ \\
\hline IBO 29 & 2 & 155 & $* 1$ & $\mathbf{x}$ & 20 & $\mathbf{x}$ & $\mathrm{F}$ \\
\hline IBO 28 & 2 & 328 & 1 & $\mathbf{x}$ & 20 & $\mathbf{x}$ & $\mathrm{F}$ \\
\hline \multirow{2}{*}{ IBO 93} & 3 & 5 & $* 1$ & $\mathbf{x}$ & 30 & $\mathbf{x}$ & $\mathrm{P}$ \\
\hline & & & \multicolumn{3}{|c|}{$1 \times 30+\mathrm{APV}$} & $\mathrm{x}$ & \\
\hline \multirow[t]{2}{*}{ IBO 95} & 6 & 52 & $* 1$ & $\mathbf{x}$ & 30 & $\mathbf{x}$ & $P$ \\
\hline & & & \multicolumn{3}{|c|}{$1 \times 30+A P V$} & $\mathbf{x}$ & \\
\hline
\end{tabular}

Abbreviations as in Tables 1 and 2. Asterisks denote doses which provoked lesion. In IBO 93 and 95 APV and ibo were injected together in the right hemisphere; ibo alone was injected in the left hemisphere. In all other animals ibo was injected in the right hemisphere. Several of these animals also received injections of axonal tracers in areas A1 and A2 of the right hemisphere.

TABLE 4. Effects of injections at different ages

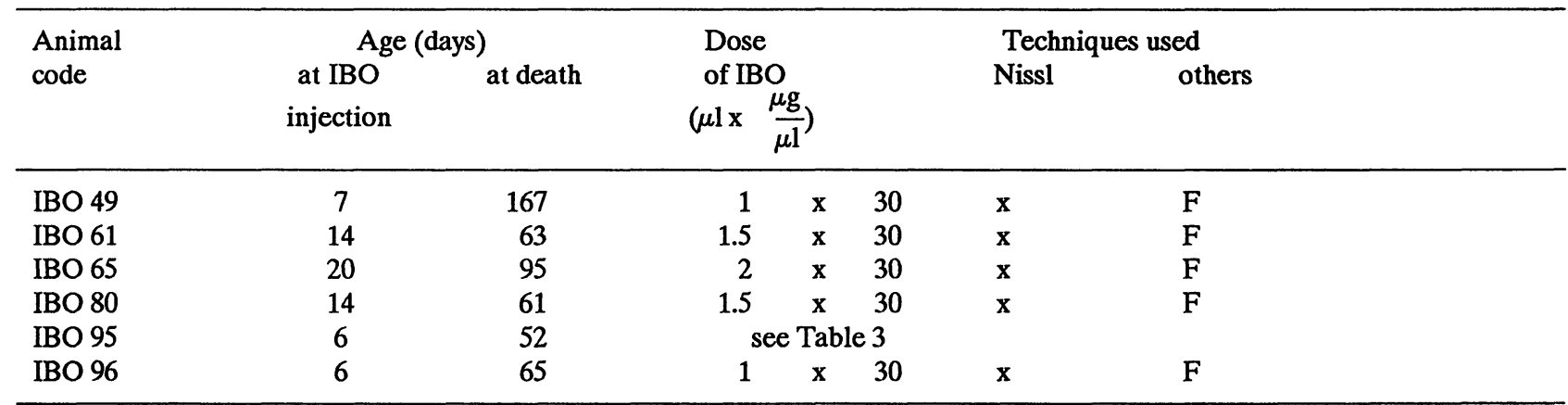

Abbreviations and concentrations as in Tables 1 and 2. All ibo injections were in the right hemisphere. Several of these animals also received injections of axonal tracers in areas $\mathrm{A} 1$ and $\mathrm{A} 2$ of the right hemisphere. 
and $1650 \mu \mathrm{m}$ in pd 14 and 20 kittens. Following 5 min waiting, ibo was injected by pressure pulses at a nearly constant rate $(0.12-0.16 \mu \mathrm{l} / \mathrm{min})$; the pipette was left in situ 3 - $5 \mathrm{~min}$ before withdrawal. With a few exceptions, only one injection, at a standard location $(5-6 \mathrm{~mm}$ rostral to lambda, $1.5-2.5 \mathrm{~mm}$ lateral to the sagittal sinus) was performed.

Following deep Nembutal anesthesia (as above), most kittens ( $F$, in Tables 1-4) were perfused with $1.5 \%$ paraformaldehyde and $1.25 \%$ glutaraldehyde in $0.1 \mathrm{M}$ phosphate buffer and $0.1 \mathrm{M}$ sucrose ( $\mathrm{pH}$ 7.4). Their brains were stored in $30 \%$ sucrose (in the same buffer) overnight. $40 \mu \mathrm{m}$ thick frozen sections, spaced $225 \mu \mathrm{m}$ from each other, were stained with $1 \%$ toluidine blue. Other kittens ( $P$, in Tables 1-4) were perfused with $4 \%$ paraformaldehyde (buffered as above). Their brains were embedded in paraffin and cut at $10 \mu \mathrm{m}$; every tenth section or more was stained with toluidine blue as above.

Two kittens (IBO 39 and 40; Table 1) were perfused with $1 \%$ paraformaldehyde and $3 \%$ glutaraldehyde in $0.1 \mathrm{M}$ phosphate buffer and $0.1 \mathrm{M}$ sucrose ( $\mathrm{pH}$ 7.4). Their brains were processed for electron-microscopy according to methods described in detail elsewhere $13 /$.

One kitten (IBO 35; Table 2) was perfused with $2 \%$ paraformaldehyde, and $3 \%$ glutaraldehyde, in $0.1 \mathrm{M}$ phosphate buffer and $0.1 \mathrm{M}$ sucrose (pH 7.4); another kitten (IBO 63; Table 2) was perfused with $1 \%$ paraformaldehyde and $1 \%$ glutaraldehyde followed by $5 \%$ paraformaldehyde and $4 \%$ glutaraldehyde (buffer and sucrose as above). In both cases, the perfusion with fixative was preceded by a rinse with the same phosphate buffer and followed by storage of the brain in the same fixative for 40 - 48 hours. These brains were processed for the Golgi technique according to a paradigm described elsewhere $/ 2 /$.

Other techniques were used in a limited number of kittens. Selected sections through the ibo injection sites of the $\left[{ }^{3} \mathrm{H}\right]$ thymidine injected kittens IBO 73 and 75 (Table 1) were processed for autoradiography using Ilford $\mathrm{K} 2$ emulsion and exposure times of 3 weeks. Other sections from the same animals and sections from IBO 90 and 97 were incubated $(1 \mathrm{~h})$ with antibodies against the glial fibrillary acidic protein (GFAP; Dakopatts) at dilution $1: 50$ or $1: 100$ or with antibodies against vimentin (Boehringer Mannheim) at dilution 1:3 and 1:6. Sections were treated with secondary antibodies and the avidinbiotin or peroxidase-antiperoxidase (PAP) visualization steps.

Selected sections from 2 brains (IBO 10 and 18; Table 2) were treated for cytochrome oxidase histochemistry $/ 65 /$.

Two human brains with cortical malformations characteristic of, respectively, microgyria and ulegyria were obtained from the neuropathology section of the Pathology Department of the University of Lausanne. As described below, these malformations are in some crucial ways similar to those obtained with neonatal injections of ibo in the cat. The first case (308SN82) was a premature girl of 35 weeks who survived 5 days after delivery. The neuropathological report indicates that the brain was microcephalic $(62 \mathrm{~g})$ and presented enormous ventricular dilation and severe malformations of brain stem nuclei. The causes of the malformations are unknown; neither toxoplasmosis nor herpetic infections could be demonstrated immunohistochemically. The pathogenic causes may have acted after the 21st week of gestation since at that age ultrasonography showed normal maturation of the skull. The microgyric malformation extended over most of the cortex in both hemispheres although some normal cortex was still found in the occipital region.

The second case (11SN77) was a 53 year old oligophrenic woman, epileptic since the age of 11. Death was caused by acute bronchopneumonia. Neuropathological examination showed slight (not quantified) microcephaly and a small (roughly $1 \mathrm{~cm}^{2}$ ) bilateral cortical displasia in the region of the calcarine fissure, which was diagnosed as ulegyria.

\section{RESULTS}

Injections of ibotenic acid in the cortex of newborn kittens induce permanent, characteristic cytoarchitectonic changes. These changes are dose and age dependent and result from reorganization of the neocortex following the early destruction.

Light- and electron-microscopic observations shortly after ibo injections 
1. Twenty-four or 48 hours after having been injected with ibo on pd 2 or 2.5 (IBO 17, 39, 73, 90; Fig. 1; Table 1), the lateral and postlateral gyri are degenerating.

The size of the lesion depends on the amount of ibo, and the severity of injury typically varies with the distance from the injection center. Near the latter, the cortex consists, in addition to layer I, of a 2-5 cell thick layer although a few wedges of intact neurons can extend further in depth, usually around blood vessels (Fig. 1). This layer is continuous with the cortical plate of the surrounding, intact cortex which, at this age, probably corresponds to the prospective layer II and the top of layer III /55/. Progressively deeper cortical layers are intact at increasing distance from the injection center. Characteristically though, the destruction of layer $V$ and of part of layer IV extends further away from the injection center than that of layer VI. At the periphery of the lesion, therefore, an empty layer is interposed between a thinned layer VI and the upper cortical layers (Fig. 8A).

The injured cortex and its underlying white
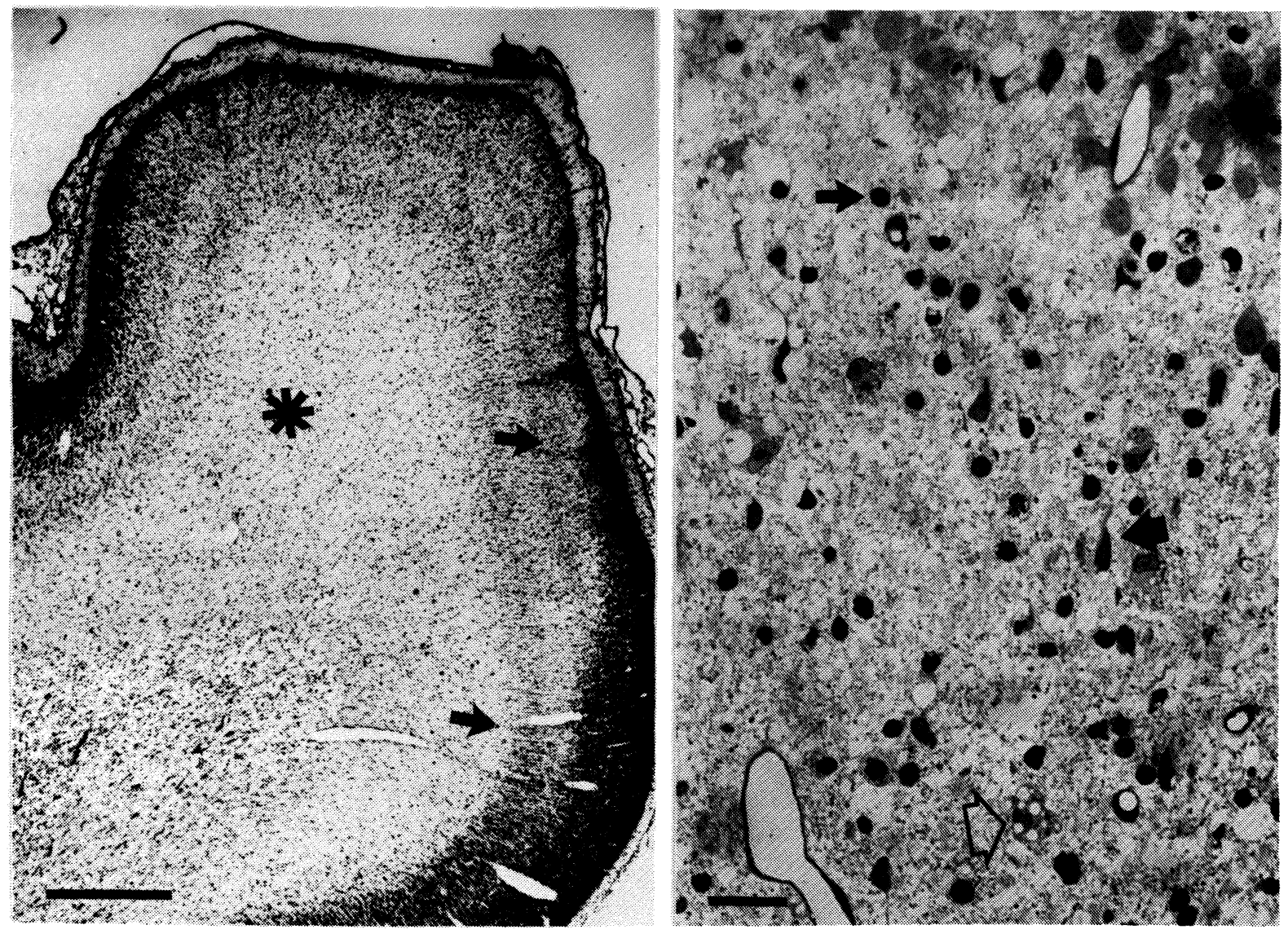

Fig. 1: Morphology of neonatal neocortex $24 \mathrm{~h}$ after ibo injection. Left: IBO $73,10 \mu \mathrm{m}$ thick paraffin section through the postlateral gyrus, near the center of injection; toluidine-blue stained. Area 17 is on the medial (right) and area 18 on the lateral (left) bank of the gyrus but the precise location of the $17 / 18$ border varies from animal to animal and cannot be determined in this material. Neurons are restricted to a thin superficial layer in most of the gyrus but extend progressively deeper at the transition with normal cortex (arrows). Right: IBO 39, toluidine-blue stained $1 \mu \mathrm{m}$ thick section through a degenerating portion of the postlateral gyrus (area 17). Pial surface is up. Notice intact neurons at the top, elsewhere pyknotic nuclei (e.g. small arrow), a few intact, probably migrating neurons (e.g. large arrow) and gitter cells (e.g. open arrow) are found. Calibration bars are $500 \mu \mathrm{m}$ on the left, $20 \mu \mathrm{m}$ on the right.

Although this cannot be stated with certainty, the center of injection was probably close to the asterisk. 
matter have a loose texture. Degenerating elements, most of them presumably neurons, typically show pycnotic nuclei, and severely vacuoled or already disintegrated cytoplasm (Figs. 1 and 2). Electron-microscopically, less advanced signs of degeneration, i.e. empty mitochondria can also be seen in some neurons. Many axons are vacuolated, or swollen, or disintegrating, but some seem intact and occasionally synapses can be seen.

Many "gitter cells" (brain phagocytes probably related to microglia; see /26/ for discussion) are interspersed among the degenerating elements (Fig. 1, empty arrow). Gitter cells have a characteristic, irregularly shaped nucleus containing patches of electron-dense chromatin, and many cytoplasmic vacuoles some of which are with inclusions, indicating intense phagocytosis. In smaller number and with different distribution than after ibo injection, these cells are a normal, albeit transitory constituent of the immature white matter where they may phagocytose naturally degenerating axons and neurons $13,24,26 /$.

In contrast, in the injured cortex and the underlying white matter, astrocytes cannot be visualized with GFAP immunohistochemistry (Fig. 3B), nor can they be unequivocally identified by cytological criteria in semithin or thin sections. In the neighbouring intact cortex (Fig. 3B) and in parts of the contralateral hemisphere corresponding to the injured cortex, GFAP visualizes numerous astrocytes which often have asymmetrically distributed processes (Fig. 3A). They are densest within a $400-500 \mu \mathrm{m}$ thick band running parallel to the bottom of layer VI, less dense in the center of the white matter and exceptional in the cortex. This distribution is of interest because the astrocyterich zone may correspond to the region where axons directed to the cortex seem to wait for some time, before entering the gray matter (see /22/ for discussion). A similar distribution of GFAP-positive astrocytes is found in the white matter underlying the intact cortex of the iboinjected hemisphere but they disappear under the injured cortex (Fig. 3B).

The radial glia are, at least partially, intact. Vimentin-positive radial processes can be seen crossing the injured cortex and they terminate with typical end feet in layer I. However, the density of both processes and end feet appears lower than in the normal cortex. Thus, some radial glia have probably been destroyed. End feet of radial glia and processes containing densely packed intermediate filaments typical of radial glia can be observed electronmicroscopically (Fig. 2, small arrows in A, B). The existence of intact, often elongated elements, oriented perpendicular to the pial surface in the injured part of the cortex and underlying white matter is characteristic (Fig. 1, large arrow). These elements have cytological features typical of neurons; they are probably migrating since they are frequently in contact with radial glia (Fig. 2, large arrows in C, D).

2. Six to eight days after an ibo injection on pd 2 or 2.5 (IBO 40, 97, 47; Table 1) the injected parts of the lateral and postlateral gyri have undergone considerable reorganization and the largest fraction of the degeneration debris has been eliminated. Near the center of injection the cortex is $100-300 \mu \mathrm{m}$ thick and consists of 3 zones (Fig. 4). The outermost zone corresponds to layer I of the surrounding intact cortex. Underneath there is a layer of densely packed, round or triangular cell bodies which is continuous with layers II and III of the intact cortex. Below this cellular layer, the tissue becomes loose and consists of a layer of sparse degenerating cells, "gitter cells" and a few intact neurons. Now, it also contains an accumulation of GFAP positive astrocytes (Fig. 3, C). Compared with younger animals, astrocytes are more frequent everywhere but particularly in the white matter of the injured cortex. Moving away from the center of the injection this deep nonneuronal layer becomes less conspicuous and is progressively replaced by the normal cortical layers in the same inside-out order described above (Fig. 8, B). The white matter contains numerous gitter cells, and a few neurons, and is traversed by axons and some processes of radial glia. Although the genesis of cortical neurons is finished at the time of ibo injections (see ref. 136/) we wondered if it may be reactivated by the ibo lesion. Therefore, $\left[{ }^{3} \mathrm{H}\right]$ thymidine labeled neurons were sought for, in two kittens (IBO 73 and IBO 75; Table 1) injected with ibo on pd 2.5, with $\left[{ }^{3} \mathrm{H}\right]$ thymidine, respectively, 12 and $24 \mathrm{~h}$ later and killed, respectively, 24 hours and 7 days after ibo-injection. None could be found. 

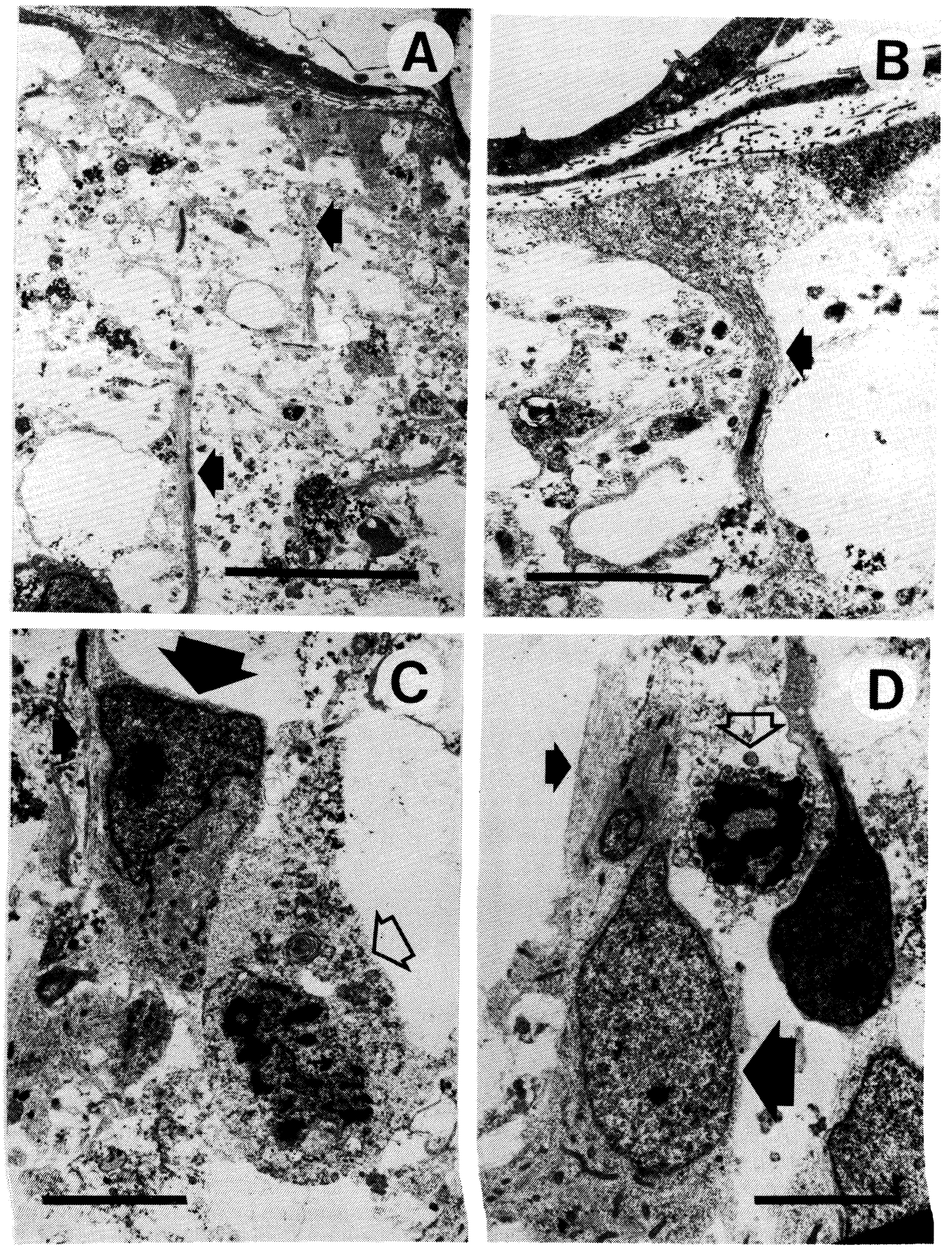

Fig. 2: Electron photomicrographs through an injected portion of area $17,24 \mathrm{~h}$ after ibo injection (IBO 39). A, B, layer I; processes of radial glia are marked by filled arrows; notice also the broad extracellular spaces and the presence of degeneration debris. C, D, degenerating cell layer, probably layer III; small filled arrows point to processes of radial glia, open arrows to degenerating cells, probably neurons; migrating neurons are denoted by large filled arrows. Calibrations are $10 \mu \mathrm{m}$ in A, $5 \mu \mathrm{m}$ elsewhere. 

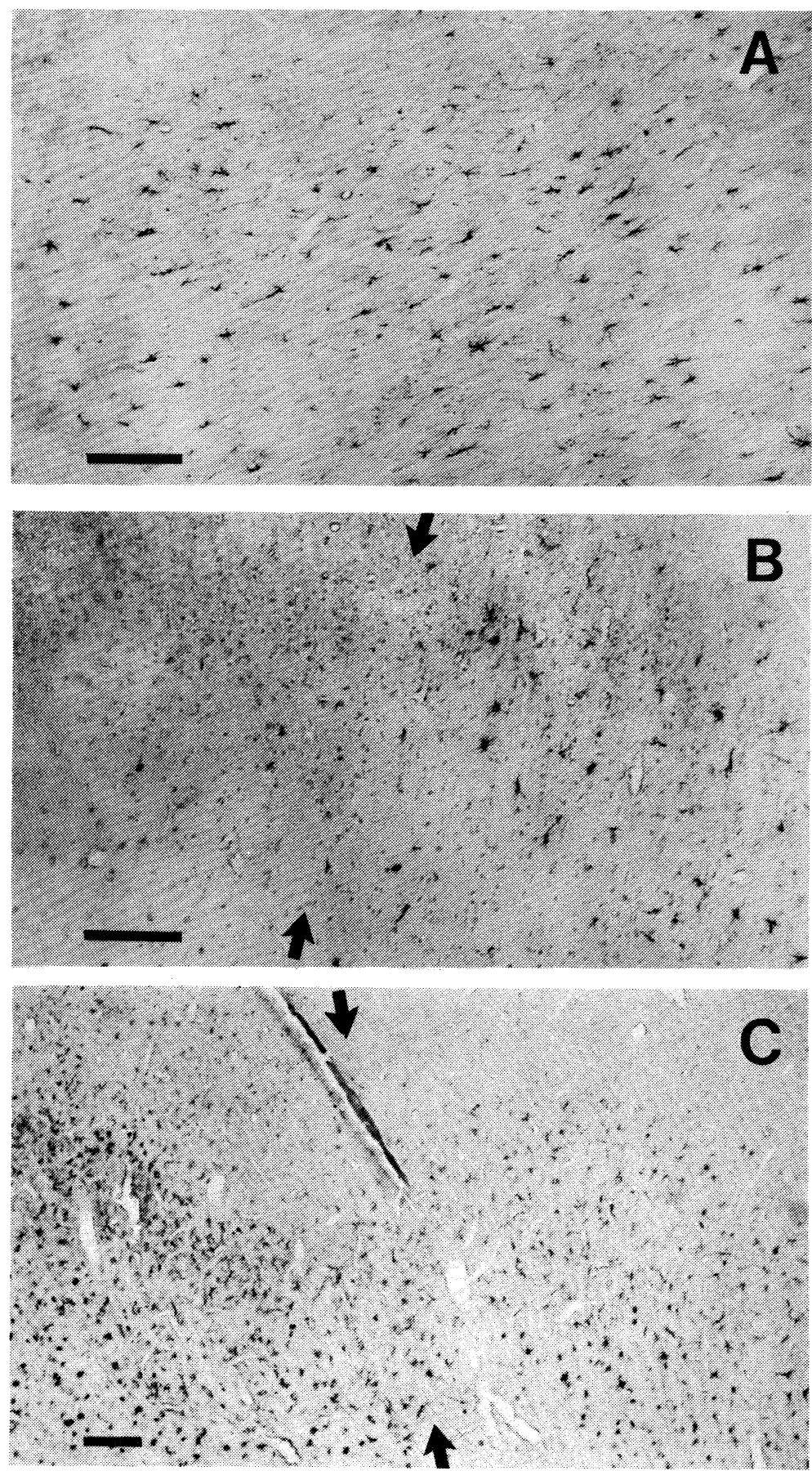

Fig. 3: Astrocytic response to the ibo injection. Photomicrographs of GFAP immunoreactive elements (PAP visualization) in the white matter, near the interface with the gray matter which is up. A, intact postlateral gyrus of IBO 73. B, transition (arrows) between the injured (to the left) and normal (to the right) portion of area 17 in the injected postlateral gyrus of IBO 73, $24 \mathrm{~h}$ after ibo injection. C, transition (arrows) between injured (to the left) and normal (to the right) portion of area 17 in the injected lateral gyrus of IBO 75, 7 days after the injection. In normal tissue GFAP-positive astrocytes are restricted to the white matter and bottom of the gray matter. $24 \mathrm{~h}$ after ibo injection, GFAP-positive elements have disappeared from the injured cortex; 7 days later, the density of GFAP-positive cells has increased everywhere but particularly at the gray matter - white matter interface in the injured cortex. Calibration bars are $100 \mu \mathrm{m}$. 
3. Two to four weeks after an ibo injection on pd 2 or 3 (IBO 92, 98, 48, 46; Table 1), the cytoarchitectonics of the injected lateral and postlateral gyri resemble those of the adult injected on pd 2 or 3 (see next section).

Occasionally, the consequences of the neonatal ibo injections are less favorable than those described above. In two of the animals studied one week after the injection (IBO 19 and 75; Table 1), in the most severely injured part of the lateral and postlateral gyri, the cortex still consists of layer I and of a 2 - 5 cell-thick layer continuous with the most superficial parts of the surrounding, transitional cortex which is undergoing reorganization. The underlying white matter contains just a few trabeculae of intact tissue and a few cells. In two other animals (IBO 45 and 104; Table 1), two-to-three weeks after ibo injection the lesion seems to have evolved towards massive destruction of the white matter and formation of cysts. In the most severely injured portions of the lateral and postlateral gyri the cortex is $50-100 \mu \mathrm{m}$ thick on average but can undergo local variations in thickness
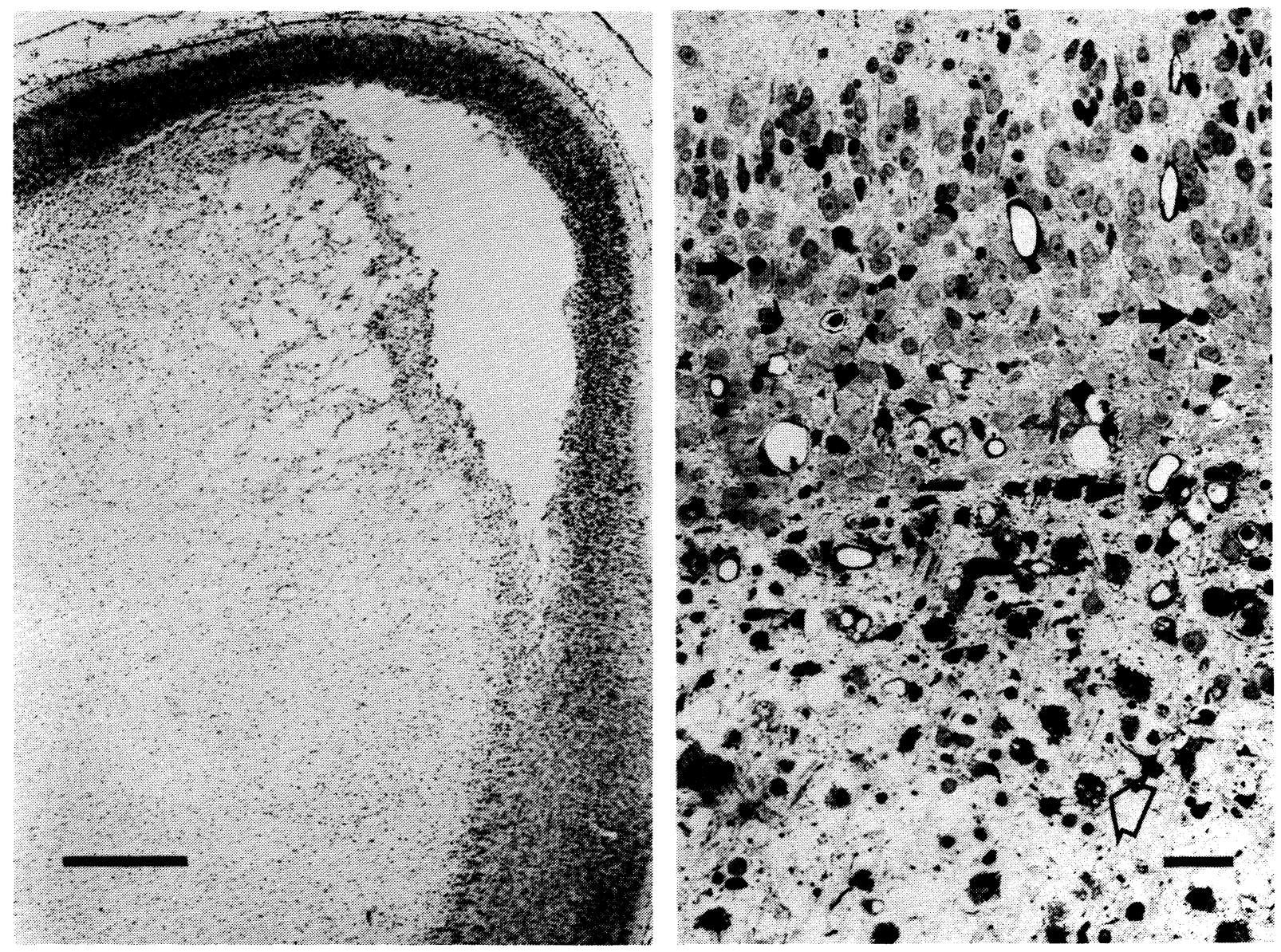

Fig. 4: Morphology of neonatal neocortex one week after ibo injection. Left: IBO 97; $10 \mu \mathrm{m}$ thick paraffin section through the postlateral gyrus, near the center of injection; toluidine-blue stained. The medial part of the gyrus (right) corresponds to area 17, the convexity (top) may in its lateral part extend over part of area 18. Notice the layer of intact neurons at the convexity of the gyrus. Tearing of the white matter underlying the injured cortex is a frequent artefact in paraffin or frozen preparation from brains studied shortly after the injection. Right: IBO 40;1 $\mathrm{m}$ thick toluidine-blue stained section through a part of the postlateral gyrus near to the center of the injection (area 17). Notice the layer of intact neurons at the top of the picture, the frequent pyknotic nuclei (dark blobs, e.g., small arrow) and gitter cells underneath (e.g., open arrow). Calibration bars are $500 \mu \mathrm{m}$ on the left, $30 \mu \mathrm{m}$ on the right. 
resembling those which are also occasionally found after longer survivals (see next section).

What causes the different evolution of apparently similar initial lesions is unclear. Secondary pathology, superposed on the ibo toxicity, may cause most severe destruction of the white matter, including the radial glia. To the extent that radial glia may be necessary for neuronal migration $/ 46 /$ the late neuronal migration which in our opinion is responsible for the recovery of cortical structure may be impaired (see Discussion).

\section{Permanent changes after neonatal ibo injections}

One month or longer after a neonatal ibo injection of $30 \mu$ or more (Table 2), narrower lateral and postlateral gyri are found on the injected side (Fig. 5). The main sulci are roughly normal in their position, but near the injection shallow and short new sulci have appeared in about $70 \%$ of the experiments. Nissl staining shows that the narrowing of the lateral and postlateral gyri is due to thinning of the gray and white matter (Fig. 6). The severity of the lesion increases towards the center of the injection. Near the lesion center, the cortex is $500-700 \mu \mathrm{m}$ thick. Below layer I, typically two cell layers can be recognized (Fig. 7). The outer layer consists of small, round cell bodies (grains), the inner layer of small and medium-size pyramids. These two layers resemble layers II and III of the surrounding intact cortex and are indeed continuous with them; they are, however, considerably thicker than these layers or the corresponding layers in the intact hemisphere (Fig. 7, A,B; Fig. 8). Away from the injection center there is a progressive reappearance of the deep layers in an outside-in order. However, destruction of layer $\mathrm{V}$ and, in some cases, of the bottom of layer IV, usually extends further away from the center of injection than that of layer VI and creates a neuron-free space between layer VI and the upper cortical layers. Further away from the center of injection only the neurons usually found in the white matter (interstitial neurons $/ 31,37 /$ ) have disappeared.

This progressive inside-out loss of the cortical layers approaching an injection center and the thickening of layers II and III are also well documented in cytochrome oxidase preparations (Figs. 8, D and 9).

While the histological changes described above can be reliably observed in all the affected brains, others are more rare. In about $10 \%$ of the cases, the gray matter is completely destroyed over several hundred microns and the white matter reaches the surface of the brain. Occasionally and in restricted regions, the bottom of the cortex undulates and the gray matter acquires uneven thickness (Fig. 7, C). The white matter underlying the lesion often contains a higher density of astrocytes than that under normal cortex. Sometimes a glial scar surrounds amorphous material. We assume that these more severe alterations of cortical structure result from the evolution of lesions similar to those in which little or no recovery was found after shorter survivals.

Impregnations with the Golgi method (Figs. 10 - 12) of parts of the lateral and postlateral gyri corresponding in normal brains to areas 17 and 18 revealed that the outer cell layer of the iboinjected cortex consists of small pyramids with short apical dendrites or of spiny stellates. The inner cell layer contains medium size pyramids and stellate cells, whose axons can occasionally be followed into the white matter. In addition, throughout the thickness of the cortex, nonspinous stellate or bitufted cells with locally arborized axons are seen. All these neurons are normal constituents of layers II and III $15,13,29,35 /$. At the bottom of the cortex, some neurons have an ovoidal cell body, and dendrites oriented tangentially to the cortical surface; they may be layer III stellates whose morphology is modified by the lesion.

\section{Effect of concentration and amount of ibo}

The severity of the cytoarchitectonic modifications depends on the amount of ibo injected (Table 3). No changes can be detected when $10 \mu \mathrm{g}$ of ibo have been injected in either 0.5 or $1 \mu \mathrm{l}$ of solution (IBO 25 and 30; Fig. 5). Indeed, in these kittens visual areas 17 and 18 of the intact and the injected hemisphere cannot be distinguished by qualitative criteria. This is also the case for one of the two kittens which received $20 \mu \mathrm{g}$ of ibo in $2 \mu \mathrm{l}$ of solution (IBO 22; Fig. 5) and for another one which received the 

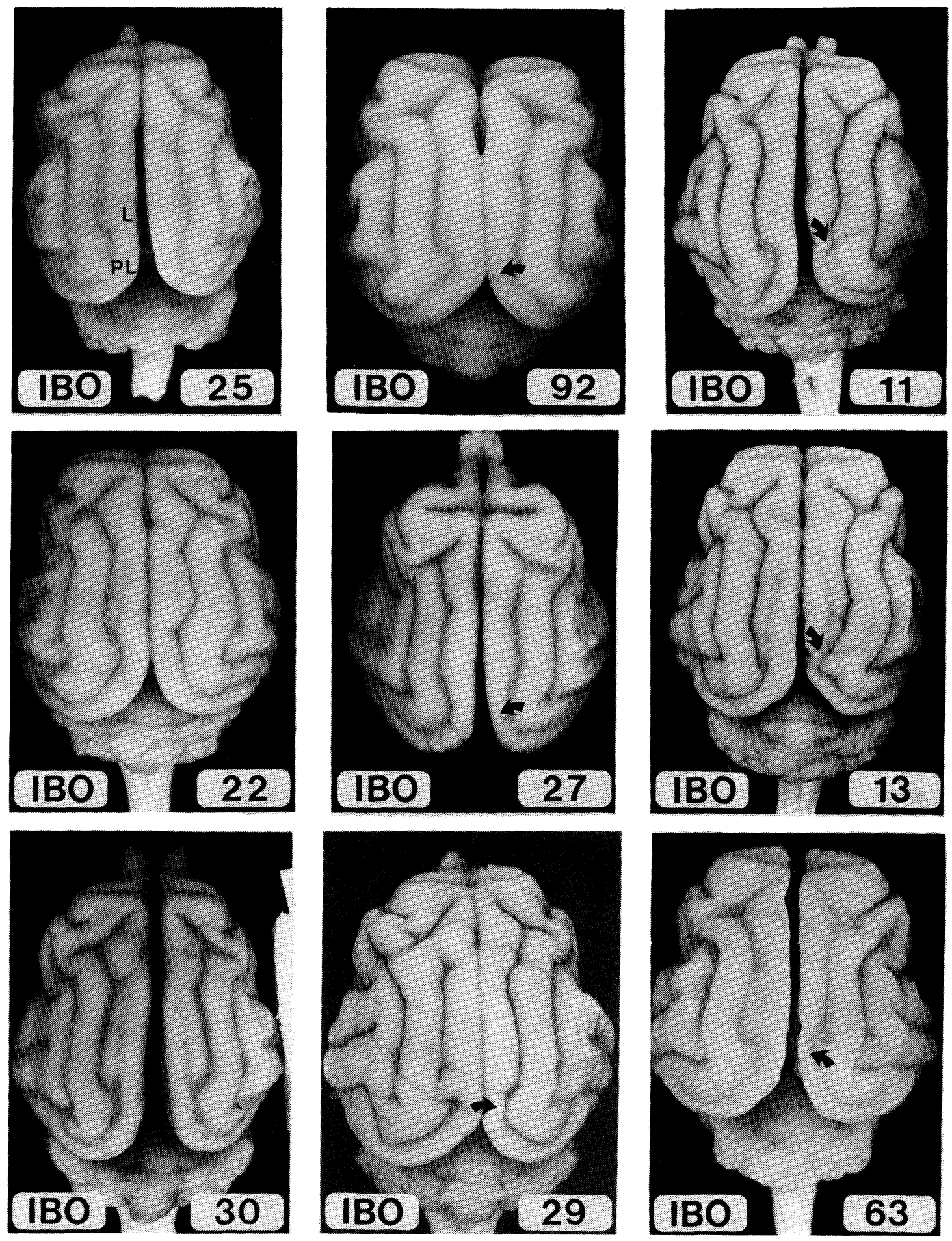

Fig. 5: Dorsal views of brains which received different amounts of ibo in the lateral (L) or postlateral gyri (PL) of the right hemisphere. In brains where the amount of ibo was sufficient to cause a lesion, arrows point to the affected portion of the gyrus. The other brains are indistinguishable from normal brains. For details concerning amounts of ibo injected, and ages at injection and perfusion, see Tables 1 and 3. In summary, no lesion could be found in kittens which received $10 \mu \mathrm{g}$ of ibo (IBO 25 and 30); $20 \mu \mathrm{g}$ of ibo caused lesion in IBO 27 and 29 but not in IBO 22. Lesions are evident in the other brains which received at least $30 \mu \mathrm{g}$ of ibo. 

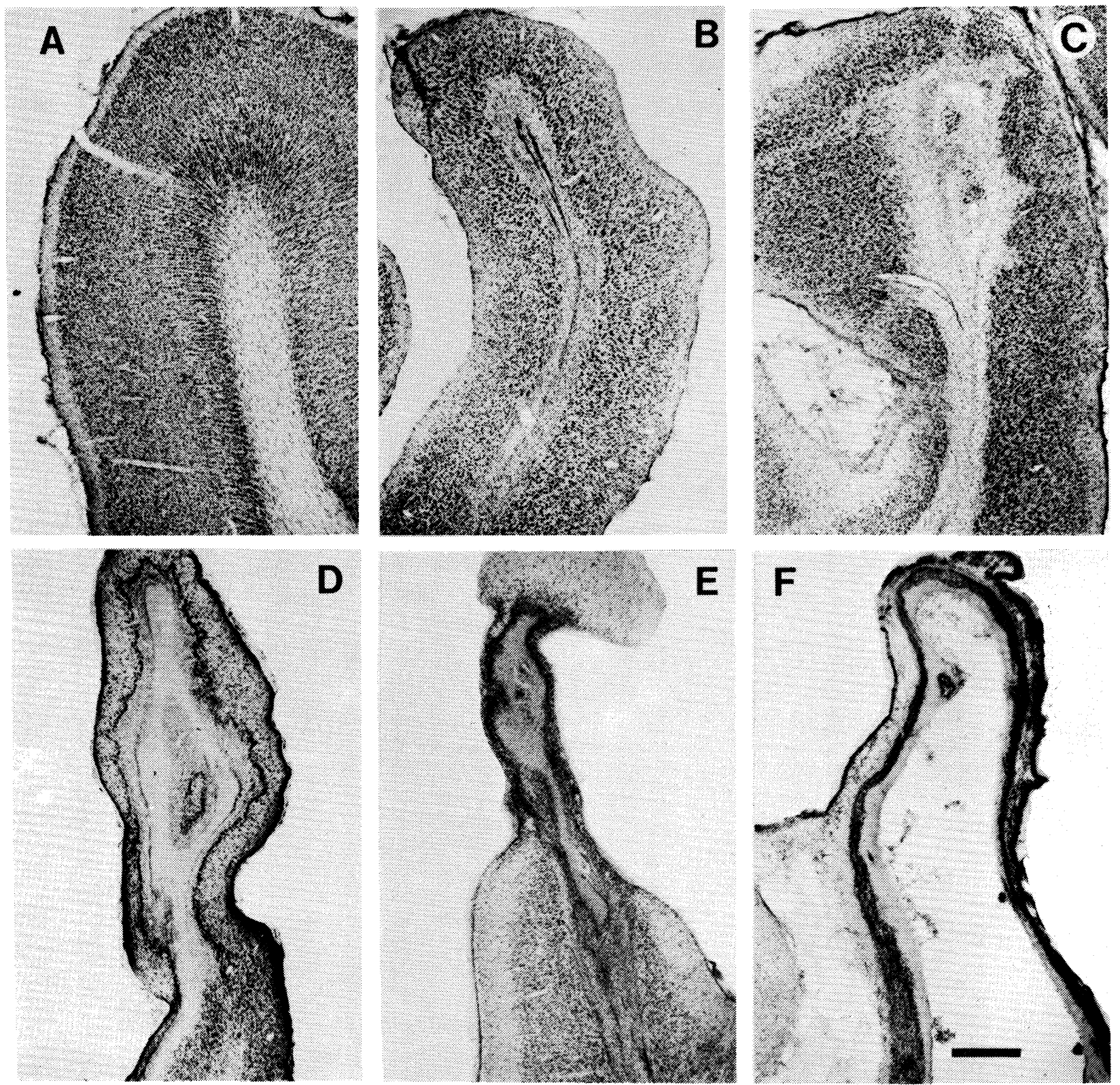

Fig. 6: Morphology of mature neocortex after neonatal injections of ibo. $40 \mu \mathrm{m}$ thick coronal sections, counterstained with toluidine blue. A, IBO 11; area 17 in the intact postlateral gyrus. B, same animal, ibo-injected postlateral gyrus. C-F, ibo-injected postlateral gyrus in IBO 18 (C), IBO 49 (D), IBO 80 (E), IBO 65 (F). Details concerning amounts of ibo-injected, age at ibo-injection and at perfusion are in Tables 2 and 4 . Notice that severity of lesion increases with age of the animal from $B-C$ (injection on pd 1 or 2) to $D$ (injected on pd 7), E (injected on pd 14), F (injected on pd 20). Calibration bar is $500 \mu \mathrm{m}$. In B-F area 17 is on the right, area 18 on the left. 

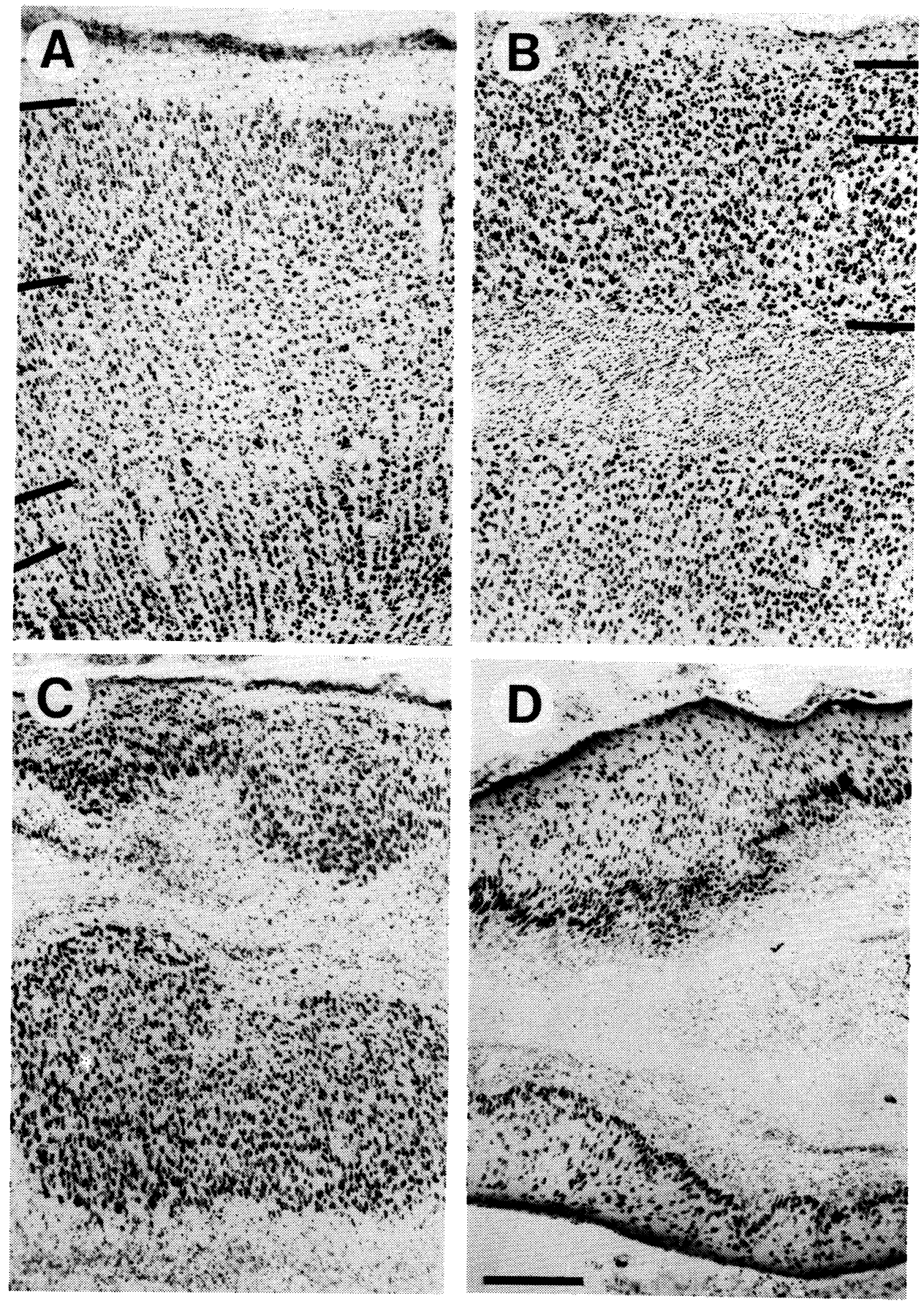

Fig. 7: Cytoarchitectonic changes resulting from neonatal injections of ibo. A, IBO 11; intact nemisphere, normal cytoarchitecture of area 17, near the convexity of the postlateral gyrus (dorsal is to the right); bars mark the bottoms of layers I, III, IV, V and VI. B, C, D the photographs span across the lateral and postlateral gyri; dorsal is to the left; each picture shows area 17 (top) and 18 (bottom). D shows a detail of Fig. 6, D. B, IBO 11; ibo-injured hemisphere, showing typical cytoarchitecture after injections on day 1 or 2; bars mark the bottoms of layer 1 , of the outer granular layer and of the pyramidal layer (see text for further explanations). C, IBO 18; ibo-injured hemisphere, showing more rare cytarchitectonic changes: the bottom of the gray matter undulates, like a festoon. D, IBO 49; in this animal injected on pd 7, areas 17 and 18 are reduced to a thin and undulating cellular layer. Calibration bar (in D) is $250 \mu \mathrm{m}$. 

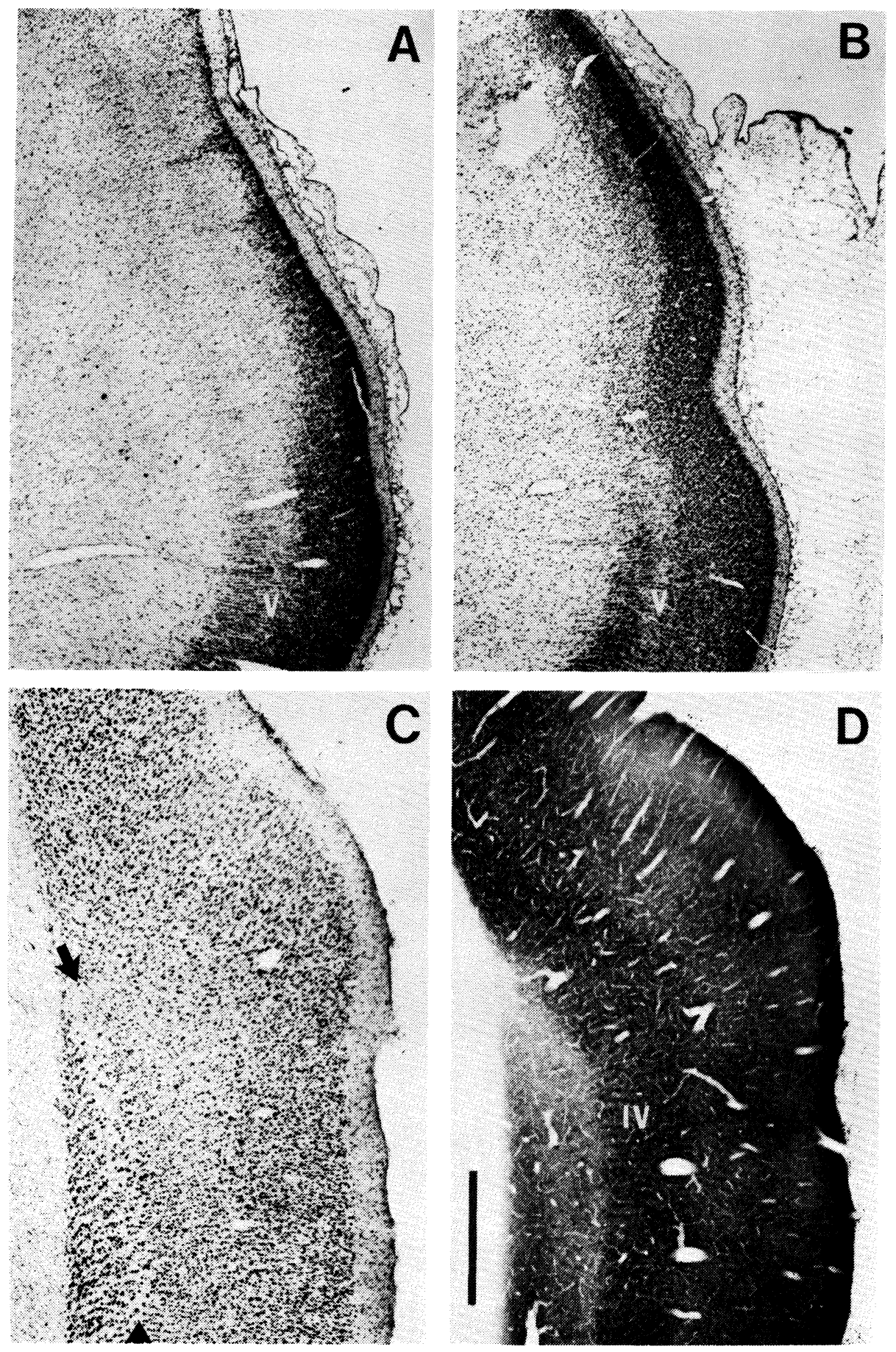

Fig. 8: Transition between the normal and ibo-injured portions of area 17, 24 hours (A, IBO 73), 7 days (B, IBO 75) and 197 days (IBO 18, C and D) after ibo injections on pd 2 or 2.5, as shown by Nissl staining (A, B, C) and cytochrome oxidase histochemistry (D). A and B are $10 \mu \mathrm{m}$ thick paraffin sections (the section in $A$ is fully shown in Fig. 1), $C$ and $D$ are adjacent $40 \mu \mathrm{m}$ thick frozen sections. Notice the progressive loss of infragranular and granular layers approaching the center of ibo injection, documented by the relative displacement of layer V (arrows in C) towards the white matter and, in D, the similar course of the cytochrome oxidase band corresponding to layer IV. Calibration bar is $500 \mu \mathrm{m}$. 
same amount of ibo in $1 \mu \mathrm{l}$ of solution (IBO 28). However, the cortex is injured in two other kittens which received $20 \mu \mathrm{g}$ of ibo either in $2 \mu \mathrm{l}$ of solution (IBO 27) or in $1 \mu \mathrm{l}$ of solution (IBO 29; Fig. 5), in a kitten which received $28 \mu \mathrm{g}$ of ibo in $2.8 \mu \mathrm{l}$ of solution (IBO 26) and in most of those which received $30 \mu \mathrm{g}$ of ibo. It must be noted that the $30 \mu \mathrm{g} / \mu \mathrm{l}$ solution is above saturation. Lesions were obtained when the suspension was injected; in a subsequent series of experiments (Assal et al., in preparation) the lesion sometimes failed to occur with $1 \mu \mathrm{l}$ injections of the supernatant of the sedimented solution. Size, location and severity of the lesions obtained with 28 - $30 \mu \mathrm{g}$ of ibo are very similar. Most of them are centered at the junction between the lateral and postlateral gyri. The core of the lesion (three layered microcortex) spans rostrocaudally over 5 or $6 \mathrm{~mm}$. At their maximal widths, the lesions extend mediolaterally over most of area 18 and the lateral two thirds of area 17 and in some animals reach area 19. Larger lesions, often involving the bottom of the suprasylvian sulcus but not the convexity of the same gyrus, are obtained with more than 30 $\mu \mathrm{g}$ of ibo.
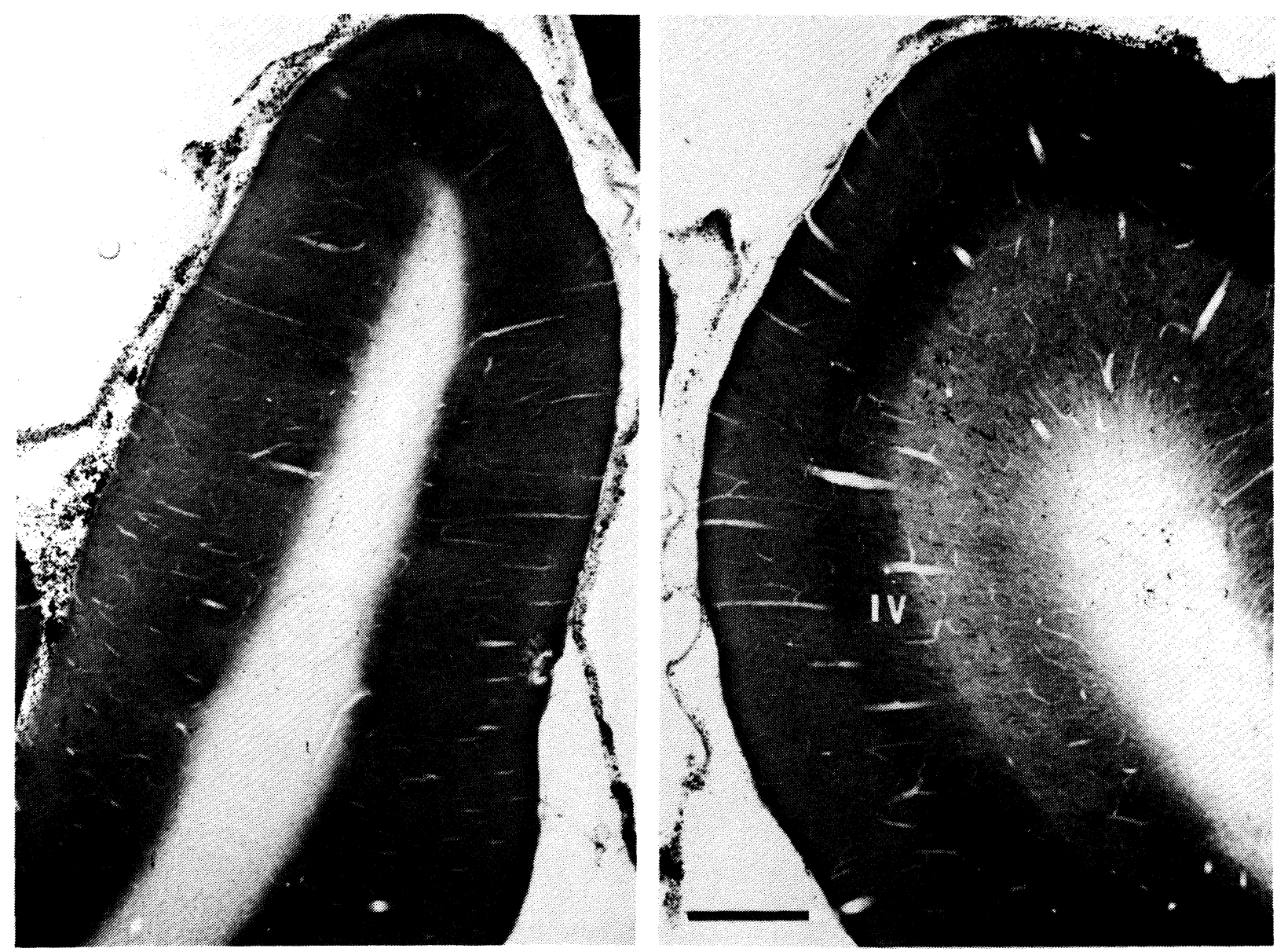

Fig. 9: Cytochrome oxidase stained preparations from the ibo-injected (left) and normal (right) hemisphere in IBO 18. Notice the absence of the cytochrome oxidase band corresponding to layer IV on the injected side, as shown in Fig. 8. The cortex on the injected side corresponds to layers III and II of the normal side but it is thicker than the latter. Medial (area 17) is between the two photomicrographs, dorsal is up. Calibration is $500 \mu \mathrm{m}$. 
In two cases (IBO 93 and 95) ibo was injected together with equimolar amounts of APV in one hemisphere, but alone in the other. Only in the latter is there a lesion, indicating that in the former hemisphere, the ibo neurotoxicity was prevented by APV (Fig. 13).

\section{Injections of ibo at different postnatal ages}

Injections of ibo on pd 6 or 7 (IBO 49, 95 and 96; Table 4) result in more severe injury to cerebral cortex than earlier injection. Near the center of the injection the cortex consists of a superficial fiber layer, wider than normal layer I and containing sparse neurons, and of a deeper, one or few cells thick layer (Figs. 6, D; 7, D, 13,
C). The superficial layer is continuous with layers I and II of the normal cortex, whereas the deep layer is continuous with layer III of the normal cortex and is characteristically undulating. At increasing distance from the center of injection, cortical layers are restored in the following sequence: first layer II, then the granular and infragranular layers following an outside-in sequence similar to that found in kittens injected on pd 2 and 3. As in the latter, the reappearance of layer VI precedes that of layer V.

Injections of ibo on pd 14 or 20 (IBO 61, 65 and 80; Table 4) result in even more severe lesions. In two of these animals (IBO 61 and 65; Fig. 6) a cyst formed at the injection site. The wall of the cyst consists of an inner $50-100 \mu \mathrm{m}$

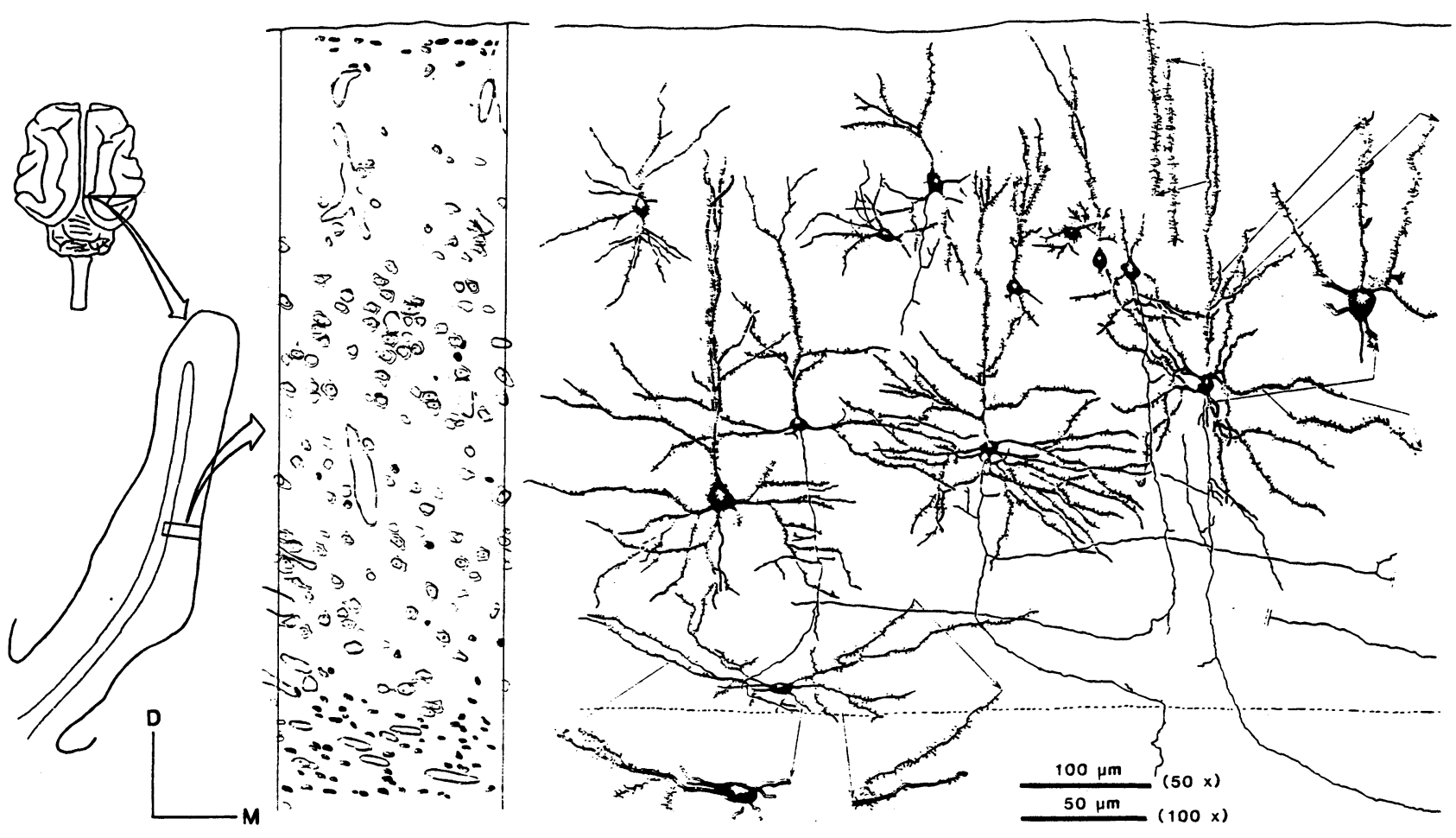

Fig. 10: Composite drawings of Golgi-impregnated pyramids or spiny stellate cells from area 17 (IBO 63) of an ibo-injected postlateral gyrus; a strip of Nissl-stained cell bodies from the same preparation shows by comparison their approximate radial position; location of the strip is shown by sketches of brain and section. An interrupted line marks the bottom of the gray matter. Location and shape of spines are accurately drawn on enlargements of parts of some neurons, as indicated by arrows. Calibration bars refer to enlargements of the main drawing and of the enlargements. Power of the objectives used for the drawings is also indicated. $D=$ dorsal, $M=$ medial, refer to orientation of the section outline. Although most of the neurons have normal morphology the tangential orientation of the dendritic arbor of the neuron nearest the white matter may be due to the lesion. 
thick amorphous layer lined outside by a cell layer containing glia and in which no neurons can be recognized in Nissl preparations. This layer is continuous with layer I of the intact cortex. Although ibo occasionally induced the formation of cysts in animals injected at younger ages (see above), a neuronal layer lined the wall of the cyst in those animals. In the third animal (IBO 80) no cyst, but an amorphous tissue containing sparse, non-neuronal cell bodies was found under the superficial glial layer. The complete disappearance of neurons in the ibo-injected region seems to be a characteristic feature of the late injections. The transition from the intact to the injured cortex tends to become sharper the older the animal at injection. Nevertheless, the destruction of the deep layers still extends further away from the injection center than that of the superficial layers.

\section{DISCUSSION}

The complexity of cortical networks raises formidable difficulties to the study of structuralfunctional relations in the adult and of cell-cell interactions in development. Against complexity, two approaches have been used: i) the experimental analysis of morphological, functional and developmental properties of single neurons or of selected neuronal populations; ii) the construction of cybernetic models, incorporating features derived from the experimental analysis as well as assumptions concerning principles of connectivity, and developmental rules, both more loosely related to experimental results.

A third possibility, in some way intermediate between those two, may be the selective deletion of parts of the cortical network in the adult or developing animal by cooling $/ 54 /$, $x$-irradiation

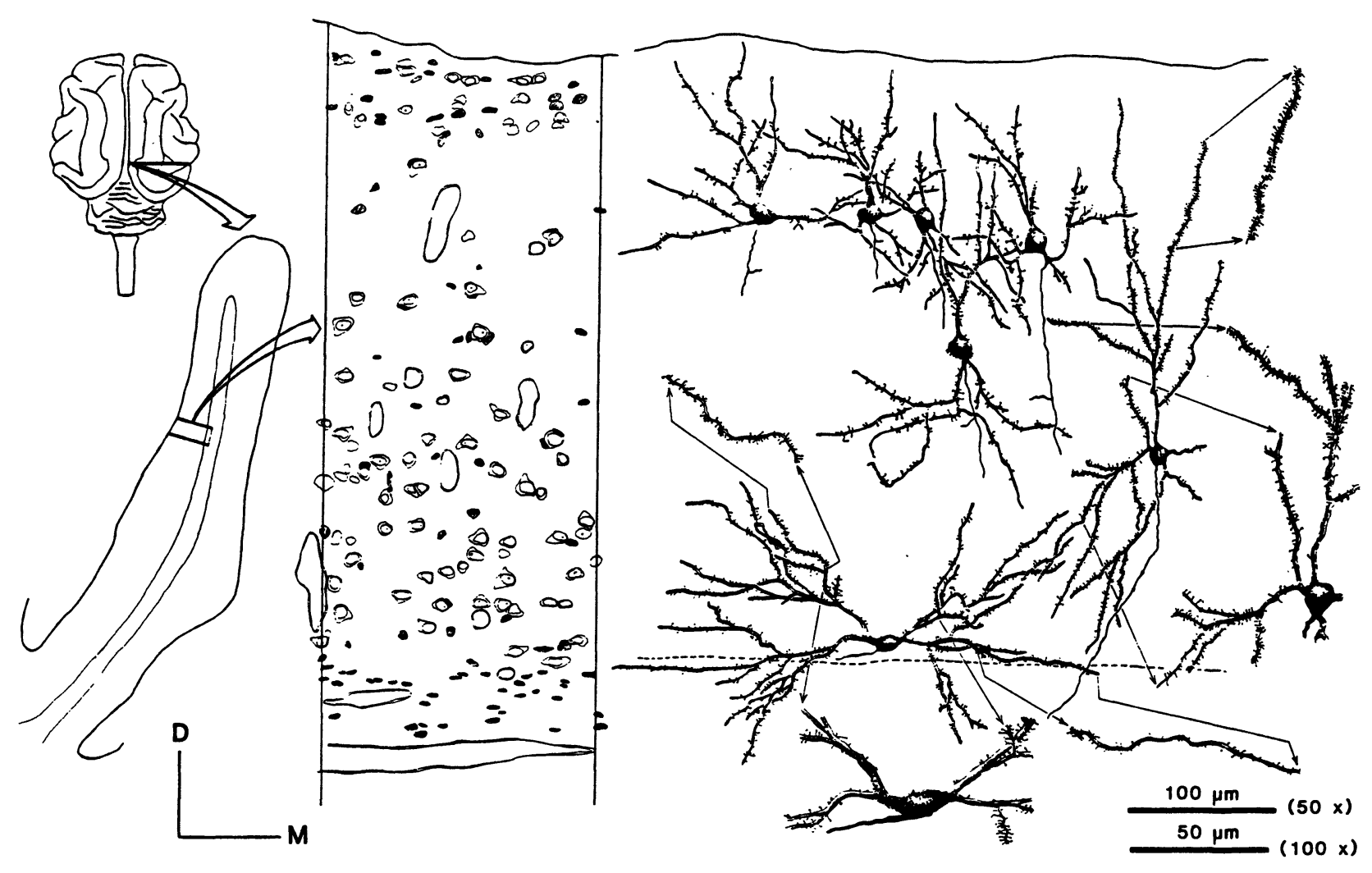

Fig. 11: Composite drawing of Golgi-impregnated pyramids or spiny stellate cells from an ibo-injected area 18 (IBO 63). Other conventions as in Fig. 10. 


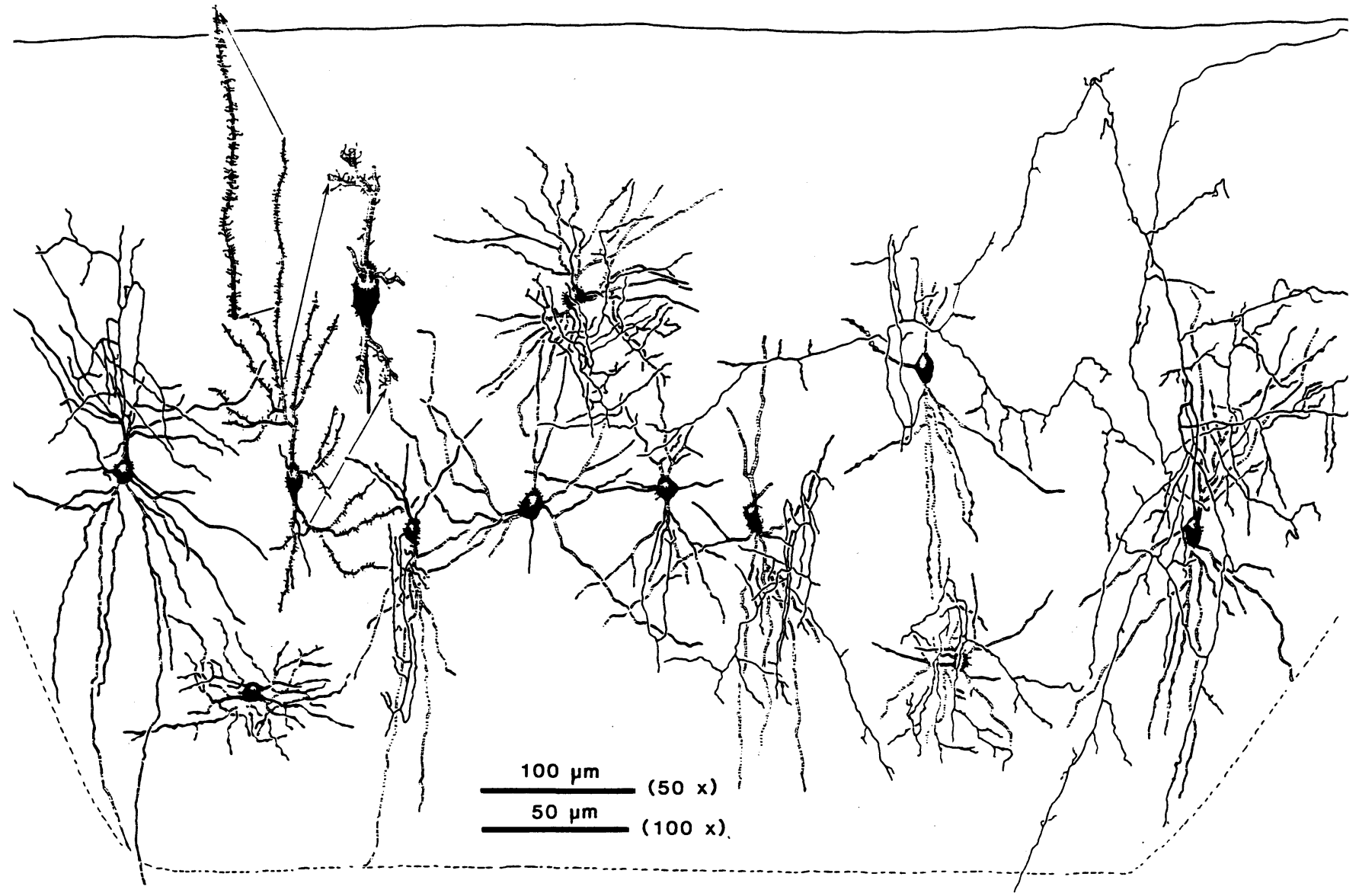

Fig. 12: Composite drawing of Golgi-impregnated, Golgi type II neurons, including both spiny and smooth stellate cells from the same parts of ibo-injected areas 17 and 18 (IBO 63) also shown in Figs. 10 and 11). Relative radial position of neurons is preserved and corresponds to that shown in Figs. 10 and 11. An interrupted line marks the bottom of the gray matter. Other conventions as in Figs. 10 and 11. 

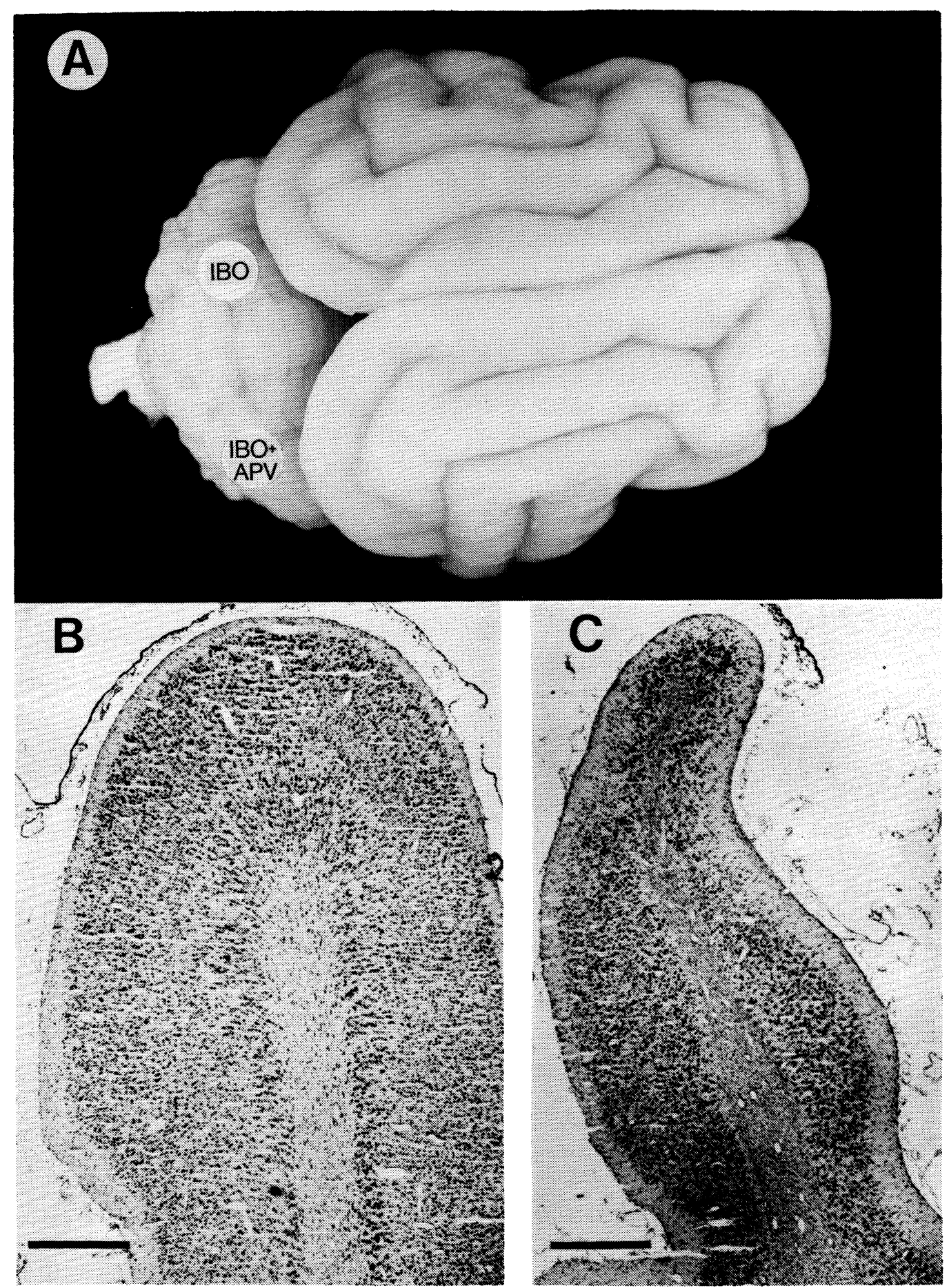

Fig. 13: A, dorsal view of the brain IBO 95. Sides of ibo and ibo + APV injections are marked; notice the narrowing of the lateral and postlateral gyri on the side of ibo but not of ibo + APV injection. B, toluidine-blue-stained, 10 $\mu \mathrm{m}$ thick coronal paraffin sections from the ibo + APV and, C, from the ibo-injected sites. Medial (area 17) is on the right in $\mathrm{B}$, on the left in C; dorsal is up. Notice the narrow gyrus in the latter. Calibration bars are $500 \mu \mathrm{m}$. 
$/ 27,28,51$, administration of cytotoxic drugs $/ 30 /$, neurotoxins (this study), or else the "enrichment" of cortical network by the injection of neuronal suspensions /40/ or the "substitution" of parts of the cortical network by grafting pieces of cerebral tissue $158 /$.

Probably, the experimental cortical networks which result from these manipulations will provide useful models for the study of structural functional relations in the adult and cell-cell interactions in development only if they can be characterized in detail and reliably reproduced. This perspective, in addition to the hope of gaining a better understanding of the mechanisms responsible for the formation of cortical connections justified the present detailed description of the structural development of cerebral cortex after neonatal injection of ibotenic acid, as well as further studies of the connections and functional properties of such a cortex /1,21/.

\section{The effects of ibotenic acid on the developing vi- sual cortex}

Ibo / 12 / is an excitotoxin $/ 53 /$ which we chose as a tool for destroying the neocortical neurons but not the axons afferent to them. Kainic acid has similar neurotoxic "axon sparing" properties in the adult nervous system /9/ and also in some immature brain structures $/ 6,7 /$, but did not show neurotoxicity in two preliminary experiments in which it was delivered in $1-2$ injections of $0.6 \mu \mathrm{l}$ each $(4 \mu \mathrm{g} / \mu \mathrm{l})$ in the lateral and postlateral gyri of pd 3 kittens. We succeeded in destroying immature cortical neurons with ibo and at least some of the axons were spared. Electron-microscopically, apparently intact axons were found in the injured cortex 24 hours after it had been injected with ibo. Some of these axons may belong to the local intact neurons. Others may be afferents and may be the source of the synapses occasionally found on intact neurons. Twenty-four hours after an ibo injection, and a simultaneous WGA-HRP injection in the contralateral hemisphere, anterogradely labeled axons can be seen at the ibo-injected site /21/.

In the developing nervous system, as in the adult nervous system, the excitotoxic action of ibo seems to be mediated by the NMDA receptor (see ref. $/ 59 /$ for discussion). As in the striatum of 7 day old rats $/ 59 /$, the neurotoxicity was blocked in both a 3 day and a 6 day old kitten by a NMDA receptor antagonist. Why the activation of the NMDA receptor by ibo kills the neuron is unclear, but one possibility is that $\mathrm{Ca}^{2+}$ dependent proteases and lipases are activated by the NMDA mediated $\mathrm{Ca}^{2+}$ entry $/ 38,49 \%$.

Three aspects of the ibo toxicity in the present study will be discussed below.

i) At the doses, concentrations and rates of delivery used here ibo seemed to affect indiscriminately all cortical neurons with the exception of early postmigratory or migrating ones. The presence of intact migrating neurons even near the center of ibo injection sites, 24 hours after the injection on pd 2 or 3 , was suggested by the light-microscopical data and unequivocally confirmed electron-microscopically. Their relative insensitivity to ibo was stressed by the proximity of degenerating elements (Fig. 2). In the same animals, at least a few of the most superficial neurons are intact. These neurons have probably completed migration shortly before or, more probably, just after the ibo injection. Why migrating neurons are spared by ibo is unclear. They may not have developed the NMDA receptor, or one of the steps leading from the latter to death of the neuron may not be working. One may wonder if in addition the contact with radial glia may have a protecting role, for example, by masking the NMDA receptors.

ii) Although all post-migratory neurons seem to be affected by ibo, they may differ in their sensitivity to it. Indeed, at increasing distance from the center of injection the lesion becomes confined to progressively deeper layers; furthermore layer $\mathrm{V}$ seems to be affected further away from the injection than layer VI. Since, as discussed above, the latest generated neurons destined to the superficial layers seem insensitive to the neurotoxin, the sensitivity to ibo might develop gradually and with an inside-out order, roughly corresponding to that of neuronal generation. The action of ibo on the deep layers might be potentiated by that of excitatory transmitter amino acids released by axon endings in the deep cortical layers and in the white matter. Indeed, during the first postnatal week, in the white matter and layer VI there are accumulations of axon endings of cortical origin, many of which are transitory $/ 8,18,22 /$, and presumably using excitatory amino acids as transmitters. Finally, the differential degeneration of the layers could simply reflect differences in the diffusion and/or accumulation of 
ibo in the extracellular space, due to the depth of the injections or to inhomogeneities in the diffusion of substances through the immature cortex.

iii) Following ibo injections, not only neurons degenerate, but also astrocytes disappear. The possibility that they degenerate is puzzling. Adult astrocytes appear to have functional receptors to excitatory amino acids (see /41/ for ref.). However, $\mathrm{Ca}^{2+}$ entry may not be regulated through NMDA receptors /43/. The degeneration of the astrocytes may be secondary to ionic changes in the extracellular space induced by neuronal degeneration $133 /$. We do not know the origin of the astrocytes which have reappeared in the white matter by six or seven days after the lesion and which probably constitute the glial scar often seen in the adults. They may be newly generated or they may have migrated from the surrounding tissue although some probably are transformed radial glia $/ 50 /$.

In the days following an ibo injection on pd 2 or 3 the cortex seems to recover partially, and, in the adult, near the center of an ibo injection site, the cortex consists exclusively of layers I-III. The latter is strongly suggested by the anatomical continuity between the layers of the ibo-injured cortex and layers I-III of the normal cortex, well documented both in Nissl and cytochrome oxidase preparations. Furthermore, the ibo-injured cortex lacks the projections originating in its infragranular layers such as those to the lateral geniculate nucleus and the superior colliculus while it maintains cortico-cortical connections which are known to originate from supragranular layers $/ 21 /$. To what extent layers II and III of the ibo-injured cortex are normal is unclear. Although with the Golgi technique several cellular components of normal layers II and III can be recognized, quantitative changes in the number of neurons in a class or in the structure and organization of dendritic arbors would have been missed by the present investigation. One difference between the normal and the ibo-injected cortex is that the recovered layers II and III are thicker than the corresponding layers of the normal cortex (see below). Another difference is that the ibo-injected cortex maintains the transient projection from the auditory cortex which is normally eliminated $/ 21,23 /$. While other differences may emerge in future studies it is remarkable that the ibo-injected cortex still shows functional features typical of the normal cortex. Re- sponses to visual stimulation can be recorded and many receptive fields are oriented $/ 1,23 /$ (Assal et al., in preparation). Thus, this simplified visual cortex may indeed provide a good model for the study of the circuitry responsible for the emergence of response properties characteristic of the cortical level of visual processing.

The recovery of cortical structure which takes place in the days following the ibo injection is probably due to the fact that migrating neurons are not killed and complete their migration. Three arguments favor this interpretation. First, the neurons destined for layers II and III complete migration during the 1st through 3rd postnatal week $/ 55 /$. Accordingly, an ibo injection on pd 6 or 7 results in a much thinner layer of intact neocortex than an injection on pd 2-3; no recovery is found after injections on pd 15 or 20 . Thus, recovery is obtained when ibo is injected before the end of migration and the extent of recovery seems proportional to the size of the neuronal pool which has not yet completed migration. Second, intact, fusiform elements, resembling migrating neurons, can be seen, both light- and electron-microscopically, in the destroyed cortex, $24 \mathrm{~h}$ after an ibo injection. Third, immunohistochemically and electron-microscopically, radial glia appear at least partially intact $24 \mathrm{~h}$ after an injection. As one would expect /46/, intact, probably migrating neurons can be seen in contact with radial glia.

A puzzling aspect of the recovery after ibo injections is that layers II and III of the ibo-injured cortex are thicker than the same layers in the intact cortex. A similar observation was reported by Dvorak and Feit /11/ following localized freezing of the newborn rat cortex (see below). Since the density of neurons in the expanded layers II and III is not noticeably less than in the corresponding normal layers, the number of neurons in these layers has probably increased. The absence of labeled neurons following the $\left[{ }^{3} \mathrm{H}\right]$ thymidine injection after ibo injection suggests that neurogenesis, which is normally finished a few days before birth $/ 36 /$, is not reactivated by the ibo injections, although negative results such as this are, by their nature, somewhat inconclusive. The most likely explanation for the apparent hypertrophy of layers II and III seems to be that either the partial destruction of glial channels resulted in an accu- 
mulation of neurons destined to the superficial layers within a reduced surface of cortex, or the loss of the deep layers protects neurons in the upper layers against the neuronal death which may occur in the developing neocortex $/ 14,16,17,45 /$. Tangential measurements of the ibo-injured cortex could clarify this issue, but are difficult since the lateral border of area 18 in the cat is ill defined by cytoarchitectonic criteria.

Some variability in the severity of the lesion was noticed in the present series of experiments and in a new series in progress $/ 1$ in kittens for which the conditions of injection (including amount of ibo, location and age of the animal) appeared very similar. While this variability turned out to be advantageous for some of the studies we performed, we are nevertheless puzzled by it. A possible cause is that the depth of anaesthesia, which was induced with Ketamine, an antagonist of the NMDA receptor /60/, may have differently protected individual kittens. On the other hand, the intensity of inflammatory phenomena following ibo-injection and neuronal destruction may vary and thus modulate the severity of lesions.

\section{Microgyria and ibotenic acid lesions}

There are striking similarities between the ibo-induced lesions and two human cortical displasias: microgyria (or polymicrogyria) and ulegyria. Both displasias usually affect circumscribed territories of the cerebral cortex. The typical human microgyric cortex forms numerous small gyri and sulci (hence its name) and is four layered. The most superficial, cell-poor layer is continuous with layer I of the normal cortex. The outer cell layer normally consists of two sublayers: the external one contains densely packed small cells and is continuous with the normal layer II; the internal one contains pyramids and is continuous with normal layer III. In Golgi studies, similar cell types were found in the normal and microgyric layers II and III /64/. Underneath, there is a cell poor layer, continuous with layers IV and V of the intact cortex and another cell layer continuous with layer VI of the intact cortex. At the transition between microgyric and normal cortex another sublayer continuous with layer IV can be found $/ 34,39,47 /$. This architecture closely resembles that found at the periphery of the ibo injection. However, in the cortex neonatally injured by ibo, layer VI is usually destroyed near to the center of injection. In the microgyric cortex, layer VI may be preserved because it is vascularized differently from the superficial layers and therefore differently affected by ischemia $/ 11 /$ which is the probable cause of microgyria. On the other hand there are many deviations from the typical microgyric pattern, and layer VI is not always preserved $/ 32,39 /$. The latter is illustrated in Fig. 14; the similarity between human microgyria and ibo-lesioned cortex is particularly clear at the transition between normal and displasic cortex.

Although ibo can induce the formation of sulci and undulations in the cell layers of the gray matter, the degree of folding is always less than that characterizing typical polymicrogyria. This difference may not be a substantial one. According to a mechanical model of cortical convolutional development $/ 48 /$, the "convolutional wavelength" (i.e., the intersulcal or intergyral distance) may be dictated by the differential growth of the different layers both in normal and microgyric cortex. There may be species, age and place differences in this differential growth since the degree of folding greatly varies across mammals. Therefore, the loss of the deep layers may not be a sufficient condition for the development of abnormal convolutions. However, the model predicts that the "convolutional wavelength" in the microgyric cortex should tend to be proportional to the thickness of the cortex. To some extent this seems also to be the case in the ibo-injured cortex, since in the animals injected on pd 6, where the thinning of the cortex is greater than in animals injected earlier, the tendency to the formation of abnormal cortical folding is also greater.

Little or no abnormal folding but severe thinning of the cortex is found in human ulegyria $/ 4,42 /$. Fig. 15 illustrates the similarity between ulegyria and the lesions provoked in the cat cortex by ibo injections towards the end of neuronal migration (e.g. Fig. 6, D and 13, C). The ulegyric cortex in this case is a thin neuronal layer continuing layer III of the normal cortex. At the transition with the normal cortex, layer VI reappears before layers $\mathrm{V}$ and IV.

The pathogenesis of human microgyria may be similar to that of ibo lesions. In both conditions, the cause seems to act before the end of neuronal migration $/ 11,39$. An experimental 

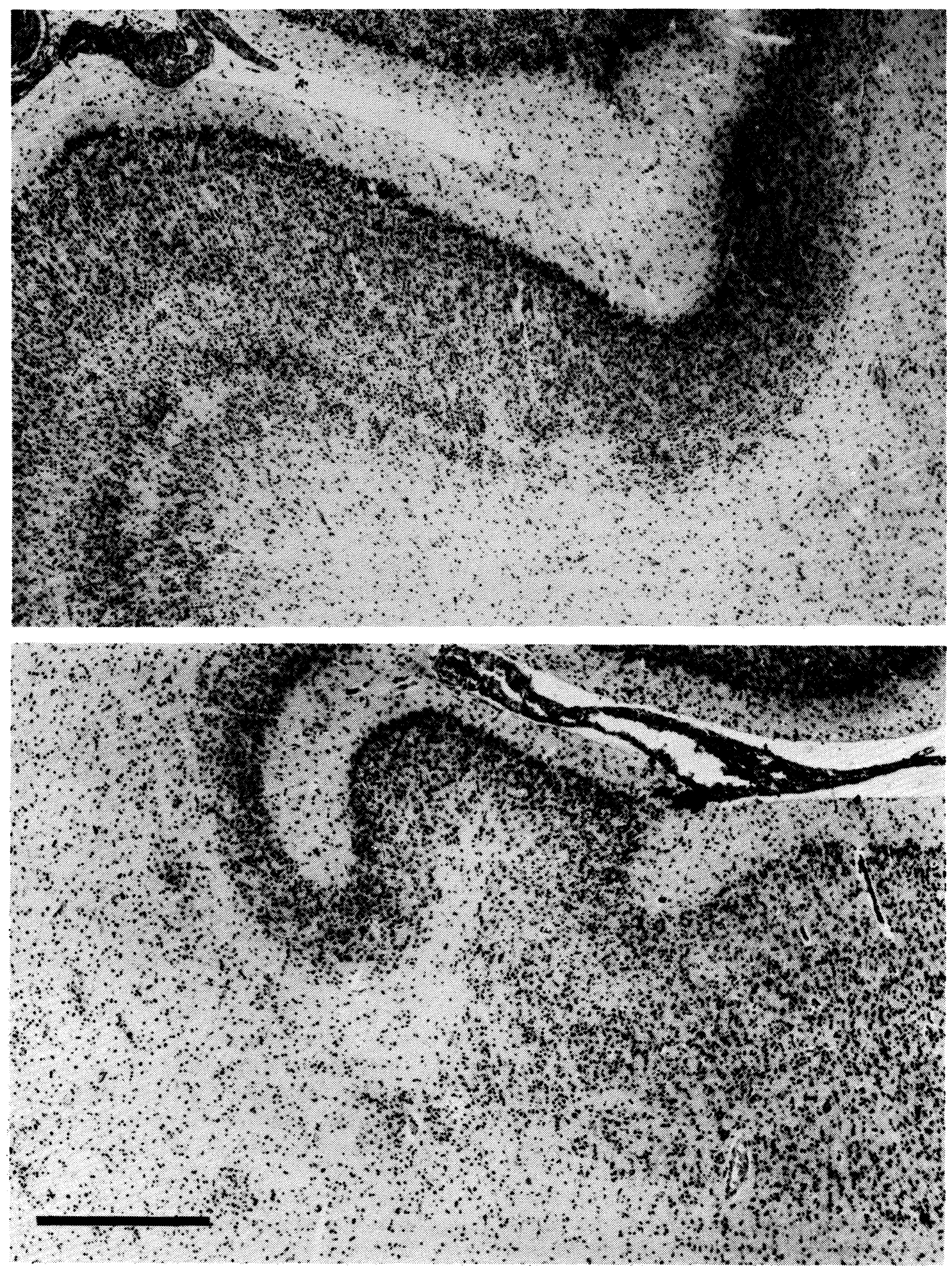

Fig. 14: Two transitions between the normal and the microgyric cortex in the human case 308SN82. Notice the progressive loss of infragranular and granular layers and the similarity with the experimental cases illustrated in Fig. 8. Calibration bar is $300 \mu \mathrm{m}$. 

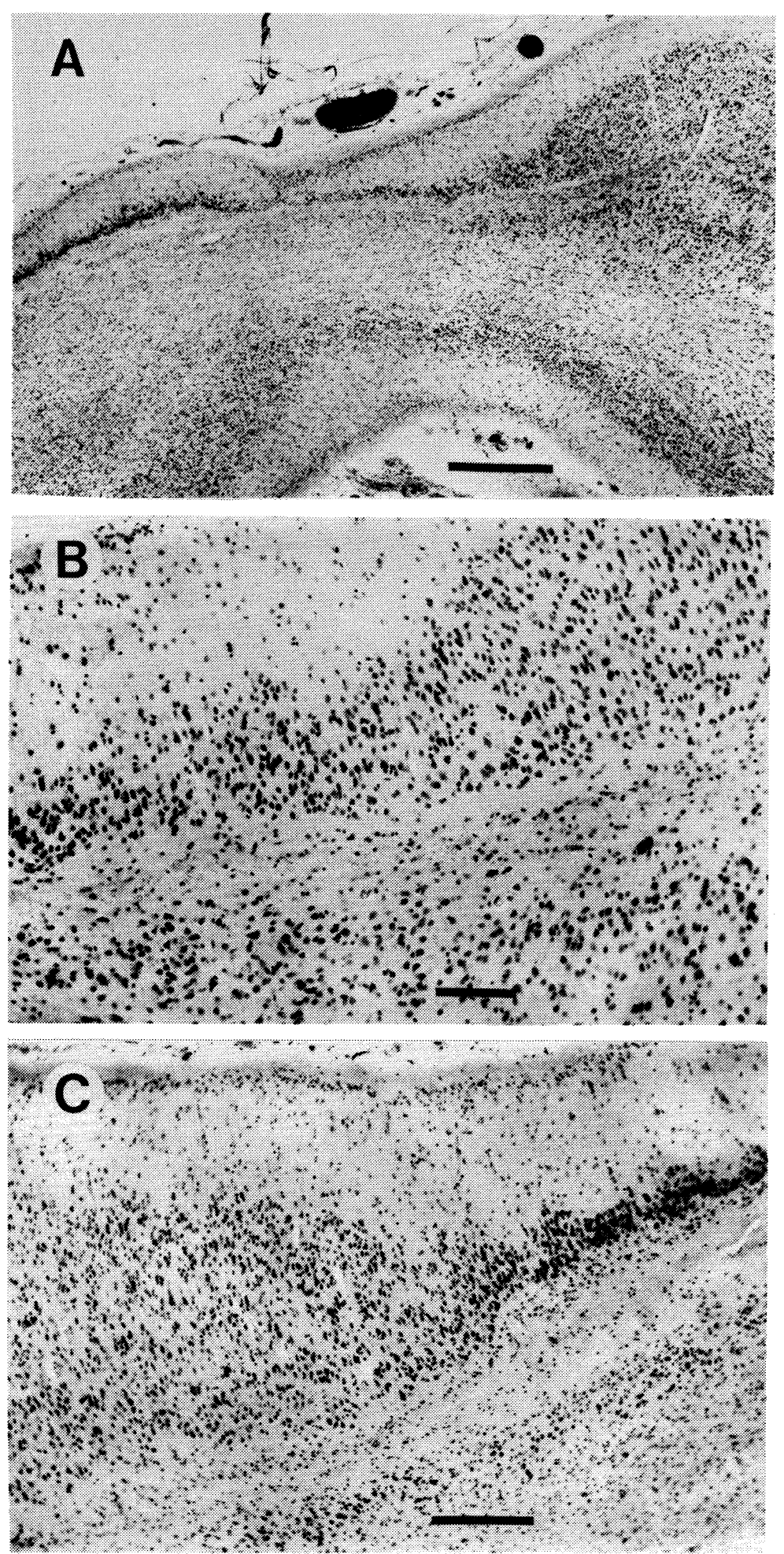

Fig. 15: Two transitions $(A, C)$ between the normal and the ulegyric cortex in the human case 11SN77. B shows an enlargement of the central portion of A. Notice the selective loss of infragranular layers and of layer II - III and the similarity with the experimental cases shown in Figs. 6, D and 13, C. Calibration bars are $500 \mu \mathrm{m}$ in $\mathrm{A}, 100 \mu \mathrm{m}$ in $\mathrm{B}, 200 \mu \mathrm{m}$ in $\mathrm{C}$. 
model of microgyria was obtained by Dvorak and Feit /11/ by locally freezing the neocortex in newborn rats. Freezing induced necrosis of variable degree but at least some migrating neurons survived the insult and continued migration, giving rise to microgyric layers II and III. This course of events resembles that described here. However, in Dvorak's and Feit's model, the neuronal migration stopped at the bottom of the region of total necrosis provoked by the lesion. Therefore, the microgyric layers II and III were infolded. The association of microgyria with porencephaly, "a deficit of the wall of the cerebral hemisphere without accompanying cranial or facial malformations" /34/, might occur if the pathological process which destroys postmigratory neurons, or secondary pathology associated with it, also destroys the radial glia, and/or the migrating neurons, thus preventing the partial recovery which leads to the formation of the microgyric cortex. Destruction of radial glia probably occurred in those experiments in which ibo injections evolved towards the formation of cysts accompanied with massive destruction of the white matter and no recovery of cortical structure.

Both microgyria and ulegyria (the latter is more rare and its pathogenesis less well understood than the former) are usually restricted to an identifiable vascular territory and this is a strong argument supporting ischemia as their cause $134,39 \%$. Recent evidence suggests an important excitotoxic component in the neuronal damage due to brain ischemia or hypoglycemia in the adult. Indeed, the glutamate levels increase in the ischemic brain and the damage due to ischemia can be prevented by specific blockers of NMDA receptors $/ 56,62 /$. Activation of the NMDA receptor may thus be the common step leading to neuronal destruction in both human microgyria/ulegyria and in the present experiments. In both conditions excitotoxicity may be enhanced by the presence in the white matter and the deep cortical layers of high levels of aspartate and glutamate released by the terminals of transitory axons as well as by the especially great efficiency of NMDA receptors in the young cortex $/ 61 /$.

\section{ACKNOWLEDGEMENTS}

This work was supported by Swiss National Science Foundation Grant 3.3590.86 to GMI, by a fellowship from the Spanish "Consejo Superior de Investigaciones Cientificas" to PB. Ibotenic acid was kindly provided by Dr. Eugster. We are grateful to P.G.H. Clarke, S. Daldoss, R. Jeanjaquet and C. Vaclavik for their help at various stages of this work. The colleagues in the Neuropathology section of the Pathology Department of the University of Lausanne and in particular Dr. Judit Miklossy were of invaluable help.

\section{REFERENCES}

1. Assal F, Melzer P, Innocenti GM. Functional analysis of a visual cortical circuit resembling human microgyria. Europ J Neurosci 1989 Suppl 2: 256.

2. Berbel PJ. Chromation at low temperatures improves impregnation of neurons in Golgi-aldehyde methods. J Neurosci Meth 1986; 17: 255-259.

3. Berbel PJ, Innocenti GM. The development of the corpus callosum in cats. A light- and electron-microscopic study. J Comp Neurol 1988; 276: 132-156.

4. Bresler. Klinische und pathologisch-anatomische Beiträge zur Mikrogyrie. Archiv für Psychiatrie und Nervenkrankheiten 1899; 31: 566-573.

5. Cajal SR. Textura de la corteza visual del gato. Trab del Lab de Inv Biol 1921; 19: 113-144.

6. Carpenter P, Sefton AJ, Dreher B, Lim W-L. Role of target tissue in regulating the development of retinal ganglion cells in the albino rat: effects of kainate lesions in the superior colliculus. J Comp Neurol 1986; 251: 240-259.

7. Catsicas S, Clarke PGH. Spatiotemporal gradients of kainate-sensitivity in the developing chicken retina. J Comp Neurol 1987; 262: 512-522.

8. Clarke S, Innocenti GM. Organization of immature intrahemispheric connections. J Comp Neurol 1986; 251: 1-22.

9. Coyle JT. Neurotoxic action of kainic acid. J Neurochem 1983; 41: 1-11.

10. Davies J, Francis AA, Jones AW, Watkins JC. 2amino-5-phosphonovalerate (2APV), a potent and selective antagonist of amino acid-induced and synaptic excitation. Neurosci Lett 1981; 21: 77-81.

11. Dvorak K, Feit J. Migration of neuroblasts through partial necrosis of the cerebral cortex in newborn rats - contribution to the problems of morphological development and developmental period of cerebral microgyria. Acta Neuropath (Berl) 1977; 38: 203-212. 
12. Eugster $\mathrm{CH}$. Wirkstoffe aus dem Fliegenpilz. Naturwiss 1968; 7: 305-313.

13. Fairén A, De Felipe J, Regidor J. Nonpyramidal neurons. In: Peters A, Jones EG (eds.), Cerebral Cortex, Vol. 1. London, New York: Plenum Publishing Corporation 1984; pp. 201-253.

14. Finlay BL, Slattery M. Local differences in the amount of early cell death in neocortex predict adult local specializations. Science 1983; 219: 1349-1351.

15. Galaburda AM, Kemper TL. Cytoarchitectonic abnormalities in developmental dyslexia: a case study. Ann Neurol 1979; 6: 94-100.

16. Heumann D, Leuba G. Neuronal death in the development and aging of the cerebral cortex of the mouse. Neuropath Appl Neurobiol 1983; 9: 297-311.

17. Heumann D, Leuba G, Rabinowicz Th. Postnatal development of the mouse cerebral neocortex. IV Evolution of the total cortical volume and of the population of neurons and glial cells. J Hirnforsch 1978; 19: 385-393.

18. Innocenti GM. Growth and reshaping of axons in the establishment of visual callosal connections. Science 1981; 212: 824-827.

19. Innocenti GM. General organization of callosal connections in the cerebral cortex. In: Jones EG, Peters A (eds.), Cerebral Cortex, Vol. 5. London, New York: Plenum Publishing Corporation 1986; pp. 291353.

20. Innocenti GM. Loss of axonal projections in the development of the mammalian brain. In: Parnavelas J et al. (eds.), The Making of the Nervous System. Oxford: Oxford University Press 1988; pp. 319-339.

21. Innocenti GM, Berbel P. Analysis of an experimental cortical network. ii) Connections of areas 17 and 18 after neonatal injections of ibotenic acid. J Neur Transplant 1991; 2: 29-54.

22. Innocenti GM, Berbel P, Clarke S. Development of projections from auditory to visual areas in the cat. J Comp Neurol 1988; 272: 242-259.

23. Innocenti GM, Berbel P, Melzer P. Stabilization of transitory cortico-cortical projections following lesions provoked by neonatal ibotenic acid injections. Neuroscience Suppl 1987; 22: S227.

24. Innocenti GM, Clarke S, Koppel H. Transitory macrophages in the white matter of the developing visual cortex. II. Development and relations with axonal pathways. Dev Brain Res 1983b; 11: 55-66.

25. Innocenti GM, Fiore L, Caminitri R. Exuberant projection into the corpus callosum from the visual cortex of newborn cats. Neurosci Lett 1977; 4: 237 . 242.

26. Innocenti GM, Koppel H, Clarke S. Transitory macrophages in the white matter of the developing visual cortex. I. Light and electron microscopic characteriśtics and distribution. Dev Brain Res 1983a; 11: 39-53.

27. Jensen KF, Altman J. The contribution of late-generated neurons to the callosal projection in the rat: A study with prenatal x-irradiation. J Comp Neurol 1982; 209: 113-122.

28. Jensen KF, Killackey HP. Subcortical projections from ectopic neocortical neurons. Proc Natl Acad Sci USA 1984; 81: 964-968.

29. Jones EG. Varieties and distribution of non-pyramidal cells in the somatic sensory cortex of the squirrel monkey. J Comp Neurol 1975; 160: 205-268.

30. Jones EG, Valentino KL, Fleshman JW. Adjustment of connectivity in rat neocortex after prenatal destruction of precursor cells of layers II-IV. Dev Brain Res 1982; 2: 425-431.

31. Kostovic I, Rakic P. Cytology and time of origin of interstitial neurons in the white matter in infant and adult human and monkey telencephalon. J Neurocytol 1980; 9: 219-242.

32. Larroche J-C. Developmental Pathology of the Neonate. Amsterdam,London,New York: Excerpta Medica 1981; 525 pp.

33. Lehmann A, Hansson E. Morphological effects of excitatory amino acid analogs on primary astroglial cultures. Neurochem Int 1988; 13: 105-110.

34. Levine DN, Fisher MA, Caviness VS. Porencephaly with microgyria: a pathologic study. Acta Neuropath (Berl) 1974; 29: 99-113.

35. Lund JS, Henry GH, Macqueen CL, Harvey AR. Anatomical organization of the primary visual cortex (area 17) of the cat. A comparison with area 17 of the Macaque monkey. J Comp Neurol 1979; 184: 599. 618.

36. Luskin MB, Shatz CJ. Neurogenesis of the cat's primary visual cortex. J Comp Neurol 1985a; 242: 611631.

37. Luskin MB, Shatz CJ. Studies of the earliest generated cells of the cat's visual cortex: Cogeneration of sub plate and marginal zones. J Neurosci 1985b; 5: 1062-1075.

38. Mayer ML, Westbrook GL. Cellular mechanisms underlying excitotoxicity. TINS 1987; 10: 59-61.

39. McBride MC, Kemper TL. Pathogenesis of four-layered microgyric cortex in man. Acta Neuropathol (Berl) 1982; 57: 93-98.

40. McConnell SK Migration and differentiation of cerebral cortical neurons after transplantation into the brains of ferrets. Science 1985; 229: 1268-1271.

41. Murphy S, Pearce B. Functional receptors for neurotransmitters on astroglial cells. Neurosci 1987; 22: 381-394.

42. Norman RM. Atrophic sclerosis of the cerebral cortex associated with birth injury. Arch Dis Child 1944; 19: 111-121.

43. Pearce B, Albrecht J, Morrow C, Murphy S. Astrocyte glutamate receptor activation promotes inositol phospholipid turnover and calcium flux. Neurosci Lett 1986; 72: 335-340.

44. Perry VH, Cowey A. Degeneration and re-organization following neonatal tectal lesions in rats. In: van Hof MW, Mohn G (eds.), Functional Recovery from 
Brain Damage. Amsterdam, New York, Oxford: Elsevier/North-Holland Biomedical Press, 1981; pp. 335-347.

45. Price DJ, Blakemore C. Regressive events in the postnatal development of association projections in the visual cortex. Nature 1985; 316: 721-724.

46. Rakic $P$. Neuronal migration and contact guidance in the primate telencephalon. Postgrad Med J 1978; 54: 25-40.

47. Richman DP, Stewart RM,. Caviness VS Jr. Cerebral microgyria in a 27-week fetus: an architectonic and topographic analysis. J Neuropathol Exp Neurol 1974; 33: 374-384.

48. Richman DP, Stewart RM, Hutchinson JW, Caviness VS. Mechanical model of brain convolutional development. Science 1975; 189: 18-21.

49. Rothman SM, Olney JW. Excitotoxicity and the NMDA receptor. TINS 1987; 10: 299-302.

50. Schmechel DE, Rakic P. A Golgi study of radial glial cells in developing monkey telencephalon: morphogenesis and transformation into astrocytes. Anat Embryol 1979; 156: 115-152.

51. Schmidt SL, Lent R. Effects of prenatal irradiation on the development of cerebral cortex and corpus callosum of the mouse. J Comp Neurol 1987; 263: 193-204.

52. Schneider GE. Is it really better to have your brain lesion early? A revision of the "Kennard principle". Neuropsychol 1979; 17: 557-583.

53. Schwarcz R, Hökfelt T, Fuxe K, Jonsson G, Goldstein $M$, Terenius L. Ibotenic acid-induced neuronal degeneration: a morphological and neurochemical study. Exp Brain Res 1979; 37: 199-216.

54. Schwark HD, Malpeli JG, Weyand RG, Lee C. Cat area 17. II. Response properties of infragranular layer neurons in the absence of supragranular layer activity. J Neurophysiol 1986; 56: 1074-1087.

55. Shatz CJ, Luskin MB. The relationship between the geniculo-cortical afferents and their cortical target cells during development of the cat's primary visual cortex. J Neurosci 1986; 6: 3655-3668.
56. Simon RP, Swan JH, Griffiths T, Meldrum BS. Blockade of $\mathrm{N}$-methyl-D-aspartate receptors may protect against ischemic damage in the brain. Science 1984; 226: 850-852.

57. Singer W. Activity-dependent self-organization of synaptic connections as a substrate of learning. In Changeux J-P, Konishi M (eds.), The Neural and Molecular Bases of Learning. Chichester, New York, Brisbane, Toronto, Singapore: John Wiley \& Sons Limited, 1987; pp. 301-336.

58. Stanfield BB, O'Leary DM. Fetal occipital cortical neurones transplanted to the rostral cortex can extend and maintain a pyramidal tract axon. Nature 1985; 313: 135-137.

59. Steiner HX, McBean GJ, Köhler C, Roberts PJ, Schwarcz R. Ibotenate-induced neuronal degeneration in immature rat brain. Brain Res 1984; 307: 117 124.

60. Thomson AM, West DC, Lodge D. A N-methylaspartate receptor-mediated synapse in rat cerebral cortex: a site of action of ketamine? Nature 1985; 313: 479-481.

61. Tsumoto T, Hagihara K, Sato H, Hata Y. NMDA receptors in the visual cortex of young kittens are more effective than those of adult cats. Nature 1987; 327: 513-514.

62. Wieloch $\mathrm{T}$. Hypoglycemia-induced neuronal damage prevented by an $\mathrm{N}$-methyl-D-aspartate antagonist. Science 1985; 230: 681-683.

63. Wiesel TN. Postnatal development of the visual cortex and the influence of environment. Nature 1982; 299: 583-591.

64. Williams RS, Ferrante RJ, Caviness V. The cellular pathology of microgyria. A Golgi analysis. Acta Neuropath (Berl) 1976; 36: 269-283.

65. Wong-Riley $M$. Changes in the visual system of monocularly sutured or enucleated cats demonstrable with cytochrome oxidase histochemistry. Brain Res 1979; 171: 11-28. 

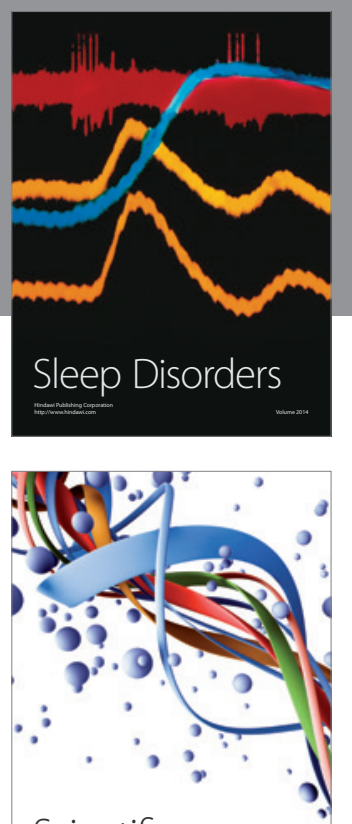

Scientifica
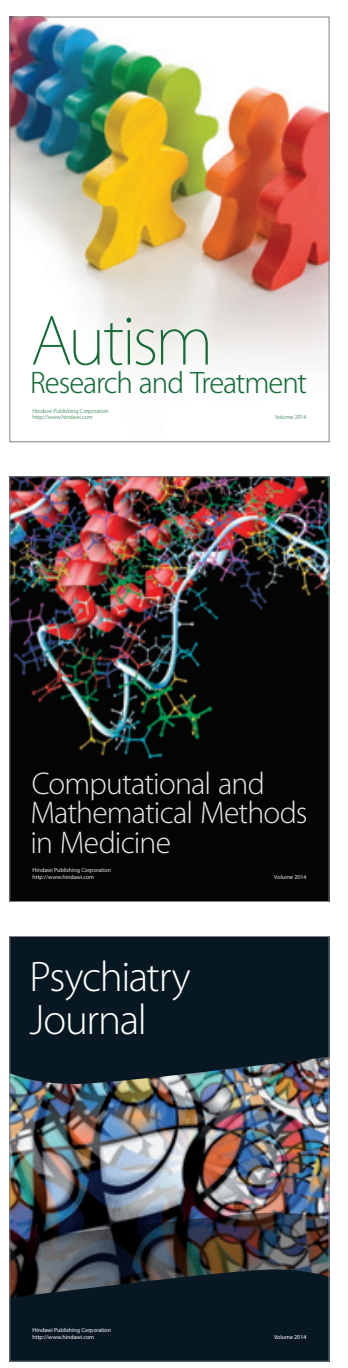
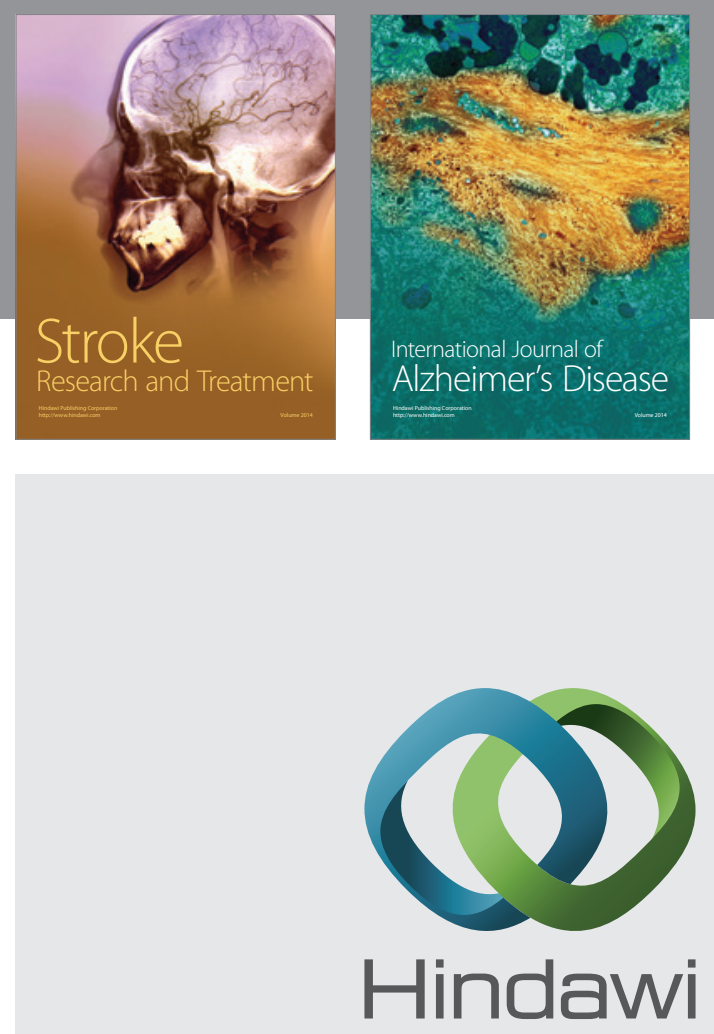

Submit your manuscripts at

http://www.hindawi.com
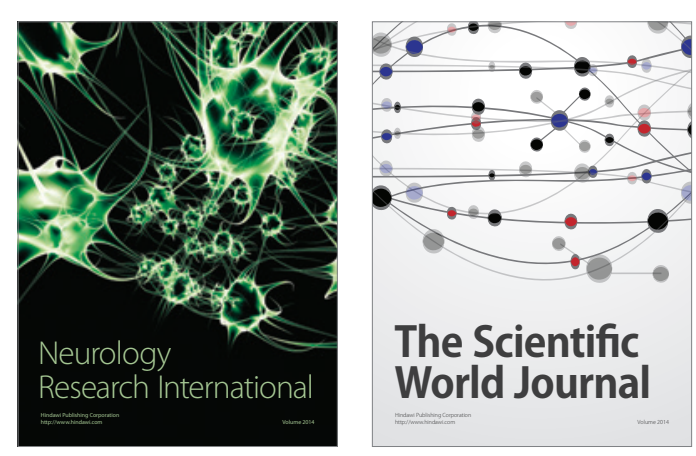

The Scientific World Journal

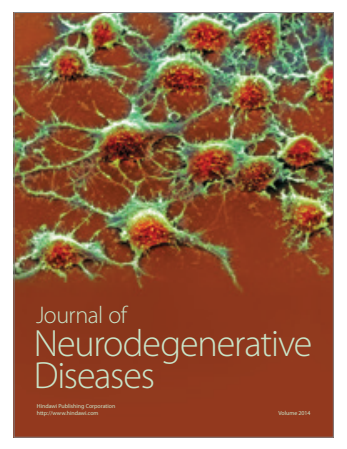

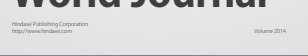

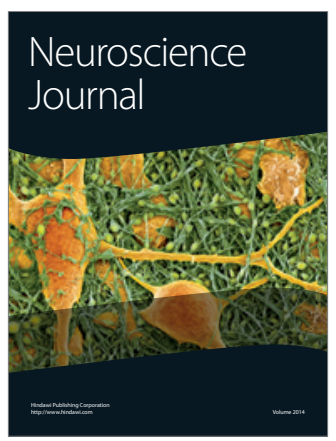

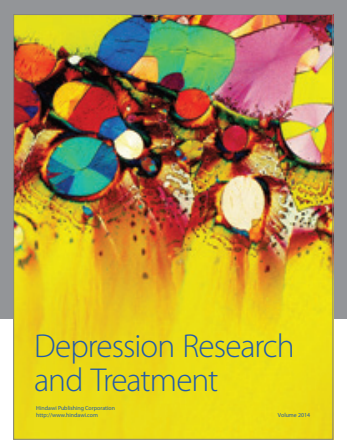
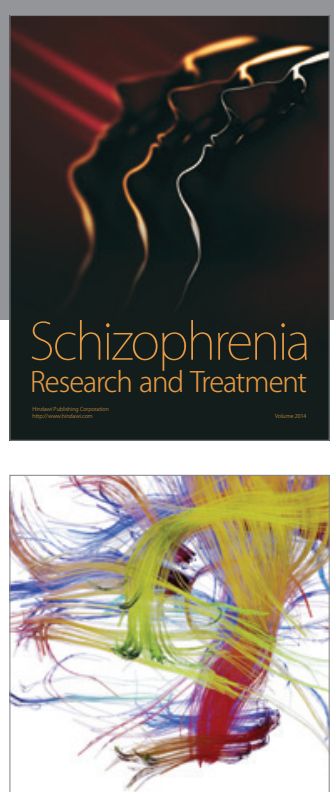

Brain Science

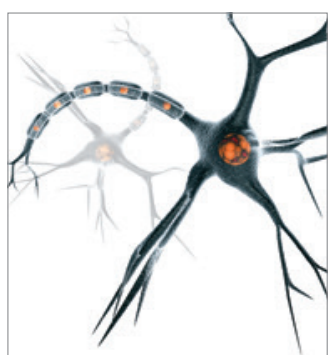

Neural Plasticity
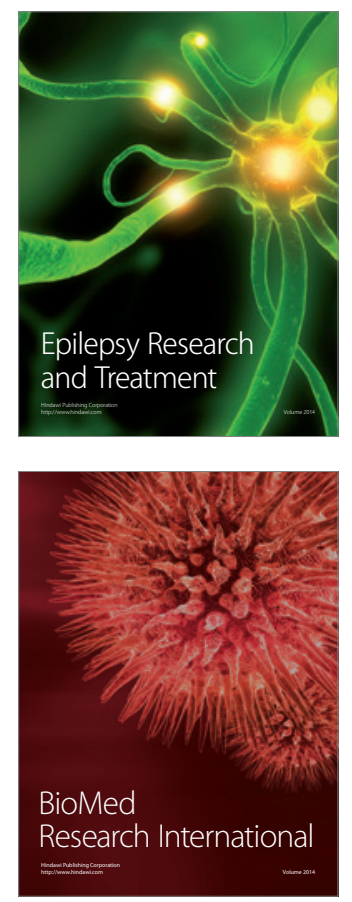

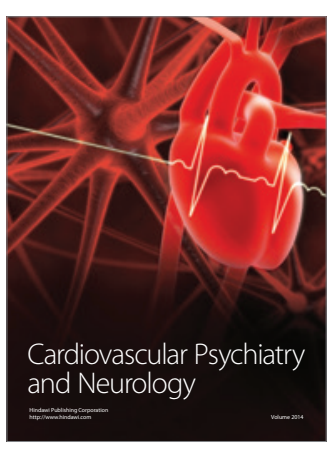

Parkinson's

Disease
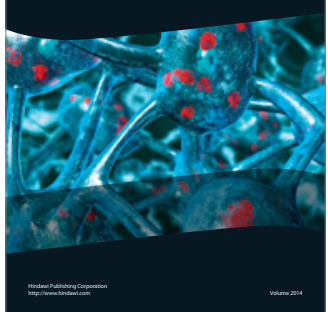